\title{
SOCIAL CONFLICT AND TRADE-UNION ORGANISATION IN THE CATALAN COTTON TEXTILE INDUSTRY, 1890-1914*
}

SUMMARY: The article deals with the development of Catalan cotton textile trade unionism between 1890 and 1914. It has been argued that, given the economic difficulties which faced the cotton textile industry, employers were anxious to cut labour costs and unwilling to negotiate with trade unions. Between 1889 and 1891 , therefore, they launched an attack on trade-union organisation within the industry. In many rural areas they were able to impose their will with relatively little difficulty. In urban Catalonia, however, they faced stiffer opposition. The state's response to labour unrest was not uniform. Nevertheless, at crucial moments the authorities supported the mill owners' assaults on labour organisation. The result was to radicalise the cotton textile labour force. This could be seen in the growing influence of socialists and anarchists in the textile unions' ranks, and in the increasing willingness of the textile workers to use general strike tactics.

\section{Introduction}

Late nineteenth- and early twentieth-century Spain has usually been regarded by historians, within a European context, as an economic backwater. In general terms this appreciation is correct. Spanish agriculture was by European standards highly inefficient, and provided only a limited stimulus to the country's economic development. Spain's weak industrial base was reflected in the fact that its main exports were minerals, wines and other foodstuffs, and that in return it imported European manufactures. Nevertheless, Spain did possess a number of industrial centres. Most of these were to be found in Catalonia, a region situated on Spain's northeast Mediterranean coast. The region's economic development was led by the cotton textile industry, and even though the industry could not keep pace with the rate of growth of its main European competitors, in the late nineteenth century Catalonia still had the sixth largest cotton textile industry in Europe. ${ }^{1}$

At this time there were about 80,000 workers employed in the industry, over a quarter of the total Catalan labour force. Overall textile workers

\footnotetext{
* I would like to thank Sebastian Balfour, Bob Fyson and Joseph Harrison for commenting on earlier drafts of this article.

1 The only general survey in English is Joseph Harrison, An Economic History of Modern Spain (Manchester, 1978).
} 
were, behind landless labourers and construction workers, the third largest category of workers in early twentieth-century Spain. Yet, little attention has been paid to trade unionism and labour politics in the Catalan cotton textile industry even by Spanish historians. ${ }^{2}$ This article, therefore, aims to fill a significant gap in our knowledge of the Spanish labour movement. Moreover, the growing body of work on textile workers in Europe allows us to compare the experience of Catalan workers with those of other countries. Such a comparison can serve the purpose of isolating the variables which help explain differences in, for example, the pattern of trade-union development and political behaviour. In this article we shall centre our comparison on England. Within Western Europe the Catalan and English cotton textile workers in many respects stood at two opposing poles. In Catalonia between 1890 and 1914 cotton textile trade unionism was very unstable. The unions were faced by an intransigent bourgeoisie, unwilling to negotiate wages and working conditions, and by a repressive state apparatus. In the northern English textile towns, on the other hand, from the 1850 s the state adopted a more conciliatory stance towards labour. Furthermore, the mill owners showed themselves increasingly willing to negotiate with trade unions. As a result, from the mid-1880s mass union federations developed in the spinning and weaving branches of the industry, and union officials entered into a system on institutionalised collective bargaining with employers. ${ }^{3}$ It is the very diversity in the experience of the English and Catalan cotton textile workers which makes it easier to chart the causes behind such different paths of development.

The study has been divided into a number of separate sections. Sections one and two chart the economic development of the industry, and the formation of an industrial proletariat in the cotton textile towns. Section three then goes on to analyse social conflict and trade-union growth within

${ }^{2}$ See however, Albert Balcells, "La Mujer Obrera en la Industria Catalana durante el Primer Cuarto del Siglo XX", in Albert Balcell, Trabajo Industrial y Organización Obrera en la Cataluña Contemporánea, 1900-1936 (Barcelona, 1974), pp. 7-121; Miguel Izard, Industrialización y Obrerismo. Las Tres Clases de Vapor, 1869-1913 (Barcelona, 1973); "Entre la Impotencia y la Esperanza. La Unión Manufacturera (7-V-1872 4-VIII-1873)", Estudios de Historia Social, 4 (1978), pp. 29-105; Pere Gabriel, “Sindicats i Classe Obrera a Catalunya, 1900-1923" (Unpublished Ph.D., Barcelona University, 1982); Angel Duarte, "Mayordomos y Contramaestres. Jerarquía Fabril en la Industria Algodonera Catalana. 1879-1890", Historia Social, 4 (1989), pp. 3-20.

${ }^{3}$ H. A. Turner, Trade Union Growth, Structure and Spread. A Comparative History of the Cotton Unions (London, 1962); Neville Kirk, The Growth of Working-Class Reformism in Mid-Victorian England (Worcester, 1985); Arthur McIvor, "Cotton Employers' Organisations and Labour Relations 1890-1939", in J. A. Jowitt and A. J. McIvor (eds), Employers and Labour in the English Cotton Industries, 1890-1939 (London, 1988), pp. 1-26. France and Germany seem to have represented intermediate cases. Employers and the state were not as willing to deal with unions as in England. Nevertheless, union members did not face the same level of hostility as in Catalonia. 
textiles, and follows the political evolution of the cotton unions. Attention is focused on a number of key questions. First, we look at employer attempts to cut costs in the industry at the expense labour, and maintain social control over the workforce. In particular, close attention is paid to a bitter conflict which developed on the spinning side of the industry over employer efforts to replace male by female workers on a new spinning machine known as the ring-frame. Second, we study the relationship between the various occupational groups within the industry, and between male and female workers. Our purpose will be to elucidate the nature of gender relations in the industry, and the extent to which workers were able to build up a sense of class solidarity across trade boundaries. Third, we assess the relative strength of reformists, socialists and anarchists within the cotton unions, and how this was to change over time. Finally, in the conclusion, the interpretation outlined will be tested against studies of the English cotton textile factory proletariat.

\section{Cotton textiles: an industry in crisis}

In Catalonia a modern textile industry grew up between 1833 and 1866. After mid-century the industry experienced sustained economic growth, and the decade between 1876 and 1886 became known as the gold fever or febre d'or. Yet Catalonia's drive to industrialise was beset by a number of problems. Not only was growth limited by the nature of the Spanish market. Catalonia had no significant coal reserves, and coal produced in Asturias was of poor quality and made uneconomic by high transport costs.

This lack of domestic coal at a time when the steam engine had become the key source of energy of the new industrial age was indeed a serious handicap. During the nineteenth century most coal was imported from Britain through the port of Barcelona. Consequently, those industrialists who set up steam-powered factories moved to the coastal plain in order to minimise transport costs. The city of Barcelona proved too cramped to accommodate the rapidly growing new industry, and it was the surrounding area known as the Pla which attracted most of the factories. Two districts in particular, Sant Martí de Provençals and Sants, became centres of cotton textile manufacture. In 1897, along with the other outlying districts, they were incorporated into Barcelona. Weaving in particular thrived in the towns around Barcelona - the so-called Mitja Muntanya - and in towns located near the coast, both to the north and south.

Imported coal, nevertheless, remained expensive. From the 1850 s, an increasing number of industrialists adopted a very different solution. They moved their establishments to the banks of rivers in order to take advantage of cheap hydraulic power. This solution was particularly attractive to the 
owners of relatively large spinning and integrated spinning and weaving mills for whom energy requirements were an important part of total costs. They congregated in two basic areas. In the first place along the rivers Llobregat and Cardoner in the districts or comarcas of the Baix Llobregat, Bagés and Bergueda. The greatest congregation of factories in this area were to be found between the towns of Manresa and Avià in the so-called Alt Llobregat. In the second place a large number of factories were to be found on the banks of the Ter and Freser further to the northeast, in the Ripollés, Osona and Garotxa comarcas. The greatest concentration of factories was to be found between the towns of Ripoll and Roda in an area known as the Ter Valley. The whole area outside Barcelona and the surrounding towns was known as the Alta Muntanya, and this term was particularly used to refer to the river-bank factories (See Figure 1).

These factories proved economically viable, for the disadvantages of higher transport costs and a lack of trained personnel were more than made up for by cheap power and, in most areas, by lower labour costs. Thus, in 1913 of the $1,800,000$ spindles employed in the industry, $1,200,000$ were to be found in establishments along the river banks of the Alta Muntanya. However, it should be emphasised that costs were only lower in Catalan terms. The rivers on which these factories operated were of the typical Mediterranean variety. They carried little water most of the year round and were liable to dry up in summer and ice up and on occasions flood in winter. In Catalonia the cost of both steam and hydraulic power was high by international standards. ${ }^{4}$

The difficulties faced by the cotton textile industry became more acute in the $1880 \mathrm{~s}$. Growth in the previous period had been dependent on the expansion of Spanish agriculture, and hence the growth in internal demand. However, the growth in agricultural production was based more on the extension of land under cultivation than to increases in productivity. In the late 1880s falling transport costs and the opening up of virgin land for grain production in Russia and North America led to the European market being flooded by cheap imports of grain. Wheat was at that time still an essential component of Spanish agricultural production. Because duties on imported foodstuffs were already amongst the highest in Europe Spain was affected later than most of Europe. However, by the mid-1880s native grain was

4 Joaquim Albareda i Salvadó, La Industrialització a la Plana de Vic 1770-1875 (Vic, 1981), pp. 57-62; Miguel Izard, Industrialización, pp. 59-60; Jordi Nadal, El Fracaso de la Revolución Industrial en España 1814-1913 (Barcelona, 1975), pp. 195-201; "La Formació de la Indústria Moderna", in Jordi Nadal and Jordi Maluquer de Motes (eds), Catalunya, Fabrica d'Espanya 1833-1936. Un Segle d'Industrialització Espanyola (Barcelona, 1985), pp. 55-56, 70; Instituto de Reformas Sociales, La Jornada de Trabajo en la Industria Textil. Trabajos Preparatorios del Reglamento para la Aplicación del Real Decreto de 24 de Agosto de 1913 (Madrid, 1914), p. 180. 

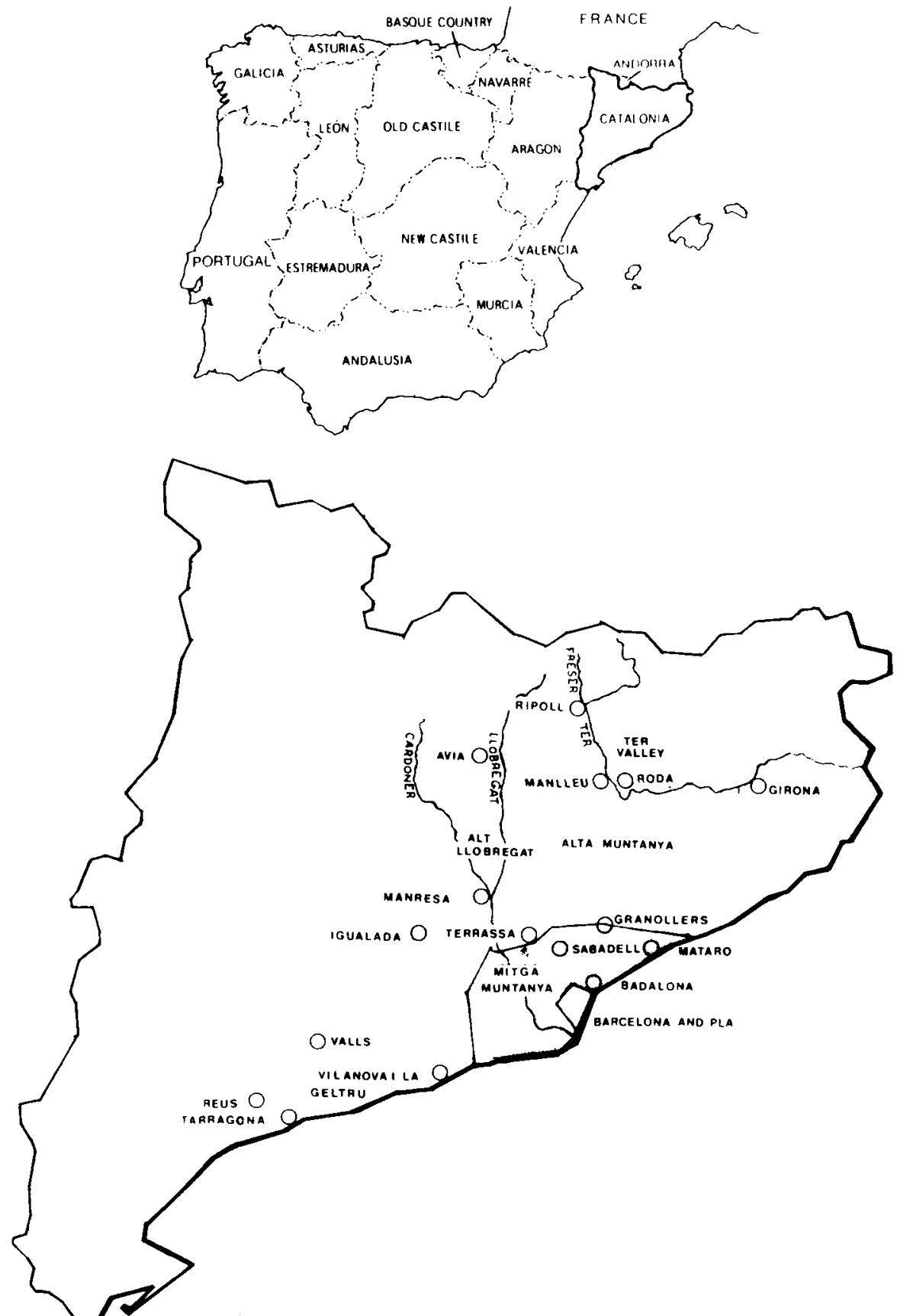

Figure 1. The geographical location of the cotton textile industry. 
being displaced by foreign imports on the Spanish periphery. ${ }^{5}$ The flood of cheap imported grains onto the home market provoked a crisis in Spanish agriculture. The purchasing power of the Spanish peasantry was, as a result, seriously affected, and this in turn led to a drastic decline in consumption of textile fabrics. The febre d'or, therefore, ended in the economic depression of 1885-1886. Industrialists, their profit margins under pressure, reacted in two ways. First, they made serious efforts to reduce costs through technological modernisation and the reorganisation of work structures in their plants. Second, they called for higher duties on cotton imports.

There were several ways in which the cotton textile industrialists could increase productivity and reduce costs. The first was through technological innovation; the second by speed ups and the intensification of labour; the third through the substitution of male by cheaper female and child labour; and the fourth simply by cutting wages and lengthening working hours. Often all four methods were very closely linked. Technically Catalan industry was near the level of its European competitors. Weaving had largely been mechanised and in spinning the modern self-acting mule predominated. Yet there was room for improvement. There were still a relatively large number of hand-looms and antiquated Crompton's mules in operation, and higher quality yarns were largely imported. Catalan manufacturers went some way towards correcting these defects in what remained of the century ${ }^{6}$ However, on the spinning side of the industry the major technological advance of this period was represented by a spinning machine known as the ring-frame.

The division of labour which operated in the spinning mills was the same as in England. Women and children were employed in most of the preparatory processes. Adult males made up only a minority of the labour force. However, they worked in the cardrooms and on the self-acting mules. These were more highly skilled professions. ${ }^{7}$ As in England the spinner worked alongside a couple of young lads known as piecers. It was his job to supervise the work done by the piecers, and they were paid out of his wages. Furthermore, a piecer could be sacked by his spinner if his work was not up to standard or he did not show due respect. ${ }^{8}$ Like their English counter-

${ }^{5}$ Ramon Garrabou, "La Crisi Agrària Espanyola de Finals del Segle XIX: una Etapa del Desenvolupament del Capitalisme", Reçerques, 5 (1975), pp. 161-216.

"Guillermo Graell, "La Industria Catalana", in El Trabajo Nacional [hereafter ETN], 30 July 1902, pp. 65-66; Pau Romeva Ferrer, Història De La Indústria Catalana (Barcelona, 1952), 2, pp. 419-420.

${ }^{7}$ For the division of labour in English spinning see, William Lazonick, "Industrial Relations and Technological Change: The Case of the Self-Acting Mule", Cambridge Journal of Economics, 3 (1979), pp. 231-262; Mary Frefield, "Technical Change and the 'Self Acting' Mule: A Study of Skill and the Sexual Division of Labour", Social History, II (1986), pp. 319-343.

${ }^{8}$ Arxiu Municipal de Torelló [hereafter AMT], T. Trabajos Varios (2). 
parts, therefore, the Catalan self-acting mule spinners played a supervisory role on the shop floor, and by limiting the recruitment of labour they could ensure they were paid relatively high wages.

In Catalonia the ring-frame had been used as an alternative to the self-acting mule since the $1840 \mathrm{~s}$, but its expansion was handicapped by relatively low productivity. However, this situation was to change in the 1870 s, when a string of bitter conflicts between self-acting mule spinners and their employers in the United States stimulated the search for ways to improve the ring-frame. The result was a number of technical advances which made the substitution of the mule for the ring-frame an attractive proposition. ${ }^{9}$ The relative advantages of the new machine were outlined in the Barcelona employer federation's mouthpiece, El Trabajo Nacional, a number of years later, when it stated: ${ }^{10}$

The ring-frame has advantages over the self acting mule with respect to the simplicity of its mechanism and the economy of its use. Its relatively simple operation permits, with all the more reason than on the self-acting mules, the employment of women and girls. It is for this reason that the ring-frame has stood out to such an extent that it has almost done away with its rival. However, in some cases it has not been able totally to replace it, and the self-acting mule is still used for yarns of higher quality. [ . . ]

Nevertheless, new technical innovations are beginning to make it possible for the ring-frame to advance in this direction.

In other words the ring-frame was more productive, and made possible a redivision of the labour force through the substitution of males by cheaper female and child labour. The fact that Catalan industry tended to specialise in the spinning of low counts of thread made its use particularly attractive and it was, as the above quotation indicates, rapidly adopted. Thus, by 1907 60 per cent of the industry's spindles were ring-frame. This represented the highest percentage of ring-frames in any European country with the exception of Italy. The pace of technological innovation in Catalonia was, in general, slower than that of her main continental rivals, but in this case she was at the forefront of change (see Table 1).

On the weaving side of the industry there were no such spectacular technological developments, but the changes which did take place were no less significant. In particular, since the mid-nineteenth century men had steadily been substituted by women on the power-looms. Thus in 1856 the Barcelona cotton textile industry had been 60 per cent male, and probably about 50 per cent of these were adults. Yet by the first decade of the century

9 William Lazonick, "Industrial Relations", pp. 256-257.

${ }^{10}$ ETN, 1 May 1912, pp. 89-92. 
TABLE 1

Number of Self-Acting Mule and Ring-Frame Spindles in Europe's Six Largest Cotton Textile Industries 1907.

\begin{tabular}{lrll}
\hline Country & $\begin{array}{l}\text { Self-acting mule } \\
\text { spindles }\end{array}$ & $\begin{array}{l}\text { Ring-frame } \\
\text { spindles }\end{array}$ & $\begin{array}{l}\text { Percentage of ring- } \\
\text { frame spindles }\end{array}$ \\
\hline England & $36,667,332$ & $6,487,393$ & 15 \\
Germany & $5,469,785$ & $3,722,155$ & 40.5 \\
France & $4,122,128$ & $2,486,977$ & 37.6 \\
Austria & $2,307,267$ & $1,277,167$ & 36.1 \\
Italy & $1,015,198$ & $1,852,364$ & 64.6 \\
Spain & 740,000 & $1,315,567$ & 60 \\
\hline
\end{tabular}

Source: F. Rahola y Tremols, "Comerc y industria de Catalunya", in F. Carrera Candi (ed.), Geografia General de Catalunya, 4 vols (Barcelona, 1980), 1, p. 397.

a number of sources suggest that adult males made up well under 20 per cent of the labour force. ${ }^{11}$

The substitution of female for male workers seems to have speeded up in the $1880 \mathrm{~s}$. Weavers were also adamant that from this period there was a constant pressure on wage-rates, and that power-loom weavers' wages had fallen to under 20 pesetas a week since $1880 .{ }^{12}$ At the turn of the century, moreover, employer attempts to cut piece rates through lengthening the pieces woven, and to raise productivity by increasing the number of powerlooms each weaver had to mind were a source of constant tension in the industry.

The industrialists' second response to the mid-1880s economic crisis was, as mentioned, to press for higher tariff duties on cotton textile manufactures. At first the central government - dominated by agrarian interests - resisted the mill owners' demands. In 1891, however, they were finally rewarded with success. Industrial tariffs were increased sharply, with duties on imported iron, steel and textiles set at particularly high levels. ${ }^{13}$ These

"Miguel Izard, Industrialización, pp. 69-74; "Censo Obrero de 1905", in Anuario Estadístico de la Ciudad de Barcelona, Ano IV, 1905 (Barcelona, 1907), p. 599; Miguel Sastre y Sama, Las Huelgas en Barcelona y sus Resultados durante el Año 1905 (Barcelona, 1907), pp. 12-13; La Jornada (1913), pp. 43, 53-54, 453-459.

${ }^{12}$ El Socialista [hereafter ES], 27 January, 3 February 1899; La Jornada (1913), p. 59. According to the labour journal Revista Social in Barcelona in 1873 power-loom weavers earned an average of 3.5 pesetas a day. In 1905 the average power-loom weaver's wage was 3.16 pesetas a day. See, Miguel Izard, "Entre la Impotencia y la Esperanza", p. 31; "Censo Obrero de 1905", p. 618.

${ }^{13}$ Jordi Nadal, El Fracaso, pp. 213-214; José María Serrano Sanz, El Viraje Proteccion ista de La Restaucación. La Política Comercial Española, 1875-1895 (Madrid, 1987), pp. 164-214; José Luis García Delgado, "Nacionalismo Económico y Intevención Estatal 1900-1930", in Nicolás Sánchez Albornoz (ed.), La Modernización Económica de España, 1830-1930 (Madrid, 1985), pp. 184-185. 
measures helped the cotton industry weather the economic storm. Thus, during the 1890 s the Catalan industrialists, further aided by a fall in the value of the peseta, were able to substitute part of the higher quality fabrics still imported. In addition Catalan mill owners began to look towards Spain's remaining colonies - Cuba, Puerto Rico and the Philippines - as an outlet for surplus production. Until the mid-1880s virtually the whole of the industry's production had been destined for consumption on the home market. From 1882, however, under pressure from cotton interests, the government agreed to remove duties on Spanish goods destined for the colonies. In 1891, moreover, substantial tariff barriers were raised on imports into the colonies from outside Spain. The result was that between 1885 and the peak year of 1897 exports as a percentage of total Spanish cotton textile production increased from 3 to 20 per cent. Yet the growth in exports was to prove a very short-term solution to the problems which faced the industry. Indeed, by encouraging an expansion of productive capacity, this growth only served to deepen the over-production crisis which was to hit cotton textiles at the turn of the century.

After a brief and disastrous war with the United States Spain lost her last colonies in 1898 . The cotton textile industry was, quite naturally, seriously affected. It could not now compete with the United States in the Antilles and, in consequence, by 1902 exports had fallen to only 6.5 per cent of total production. ${ }^{14}$ The industry was, nevertheless, able to fend off total disaster. During the first decade of the twentieth century there were productivity gains in some sectors of Spanish agriculture, and sales of cotton garments increased as a result. Moreover, desperate efforts were made to find alternative foreign markets, and some success was achieved in South America. This did not, however, suffice to lift the cloud of gloom which hung over the industry. Throughout the period 1900-1914 it suffered from chronic over-production, which fierce competition between manufacturers only served to exacerbate. ${ }^{15}$

The major difficulty faced by the industry was that, despite technological renewal, in international terms it remained uncompetitive. Quite apart from high energy costs, its plants remained smaller than those of its international competitors, and the limitations of the internal market made

${ }^{14}$ ETN, 16 September 1907, p. 454; Eusebio Bertrand i Serra, "Un Estudio sobre la Industria Algodonera", Boletín del Comité Regulador de la Comision Textil Algodonera (March, 1929), pp. 81-98. Carles Sudrià, "La Exportación en el Desarrollo de la Industria Algodonera Española, 1875-1920”, Revista de Historia Económica, year 1, 2 (Autumn, 1983), pp. 369-386.

is ETN, 1 July 1904, p. 257; 16 July 1909 , p. 237. Particularly hard hit by the need to cut production were the Alta Muntanya industrialists who used hydraulic power, for they usually rented the water at a fixed price. The more they used, therefore, the cheaper it became. It was already the case that they had to limit output part of the year due to lack of water. Between 1900 and 1914 , however, they found that often they could not work at full production even when water was abundant. La Jornada, pp. 49-50. 
product specialisation difficult. Thus in 1884 the Catalan economist, Andrés de Sard, pointed out that the average English spinning factory had between 40,000 and 50,000 spindles, while the average Catalan factory had under $10,000 .{ }^{16}$ Little had changed by the turn of the century. Overall in weaving the factory worker ratio was 1:52. The average spinning factory was larger and averaged 121 workers, but the number of spindles per factory was still only about $5,700 .{ }^{17}$ These figures probably underestimated the number of small weaving workshops that continued to operate throughout Catalonia. What they do indicate, however, is that although a true factory-based industry had grown up, factory size still by no means matched that of the British, German and French enterprises. The drawbacks of this situation were summed up by a commission of leading cotton textile manufacturers, who stated in 1906: "A greater industrial concentration is necessary. Small factories are expensive and uneconomic because they have to distribute general costs over a smaller production, and because of the greater cost of machinery." 18

\section{The formation of the cotton textile labour force}

The geographical location of the cotton textile plants was, as the above sections indicate, very varied. Some factories were to be found in large towns and cities. Others set up on river banks, near small villages, or even in totally rural settings. The nature of the workforce employed, in consequence, also varied greatly. Furthermore, while weaving predominated in lowland areas, spinning prevailed along the Ter and Freser river banks. The skills required and the division of labour in these two branches of the industry were also very different.

Many industrialists who moved to rural areas were able to employ peasants from the surrounding countryside. The employment of "mixed" peasant and industrial workers continued throughout the whole period under study. Men were sometimes employed in factories, but it was more common for them to work on the land, while some members of the female peasant household laboured in the local textile mills. ${ }^{19}$ The employment of mixed workers made it possible to pay lower wages than in Barcelona and

${ }^{16}$ Andrés de Sard, Comparación entre el Actual Estado de Desarrollo de La Industria Algodonera en Inglaterra y el de La Propia Industria en España (Barcelona, 1884), p. 16. ${ }^{17}$ ETN, 30 December 1901, pp. 195-197; 16 May 1911, pp. 239-240; Boletín de la Industria y Comercio de Sabadell, January 1913; Federación Internacional de Industrias Algodoneras. Memoria del Congreso Celebrado en Bremen los diás 25 al 29 de Julio de 1906 (Barcelona, 1907).

${ }_{18}$ Memoria del Congreso Celebrado en Bremen, pp. 199-200.

19 José Elías de Molins, La Mujer Obrera en las Ciudades y en el Campo (Barcelona, 1913), pp. 74-75; La Jornada, p. 449. 
the surrounding towns. Workers in rural areas had little or no experience of trade-union organisation. Furthermore, they often had to travel several miles to work each day, and lived in isolated farmhouses. In such circumstances it would be almost impossible to build up the on and off the job solidarity necessary for collective action to be taken. However, at the same time, industrialists found it difficult to create the kind of trained, disciplined, labour force needed for constant industrial production. The mixed workers were still very much attached to the rural peasant economy. They were, consequently, difficult to train as industrial proletarians, and often abandoned their factories when needed on the land. ${ }^{20}$

Small-scale industrialists, who specialised in weaving and often worked for larger Barcelona-based concerns, had no choice but to use the mixed workers. The industrialists who built the relatively large spinning and integrated spinning and weaving mills on the Catalan river banks needed to find an alternative. They aimed to form a relatively stable labour force over which they could impose social control, and many were able to do this by building company towns (colonies industrials).

The larger company towns, most of which were to be found in the Alt Llobregat, consisted not only of the factory premises, but also had housing for the workers, shops, provided after hours entertainments, and they often had a school and a church. The workers' every need was, thus, catered for. This was in fact necessary because some of these establishments were as much as 10 kilometres from the nearest town. Social control was maintained through a mixture of employer paternalism and strict labour discipline. The workers were typically very isolated from the outside world. There were controls on the kind of press they could read. The left-wing press was usually totally prohibited, and trade unions were banned.

Indeed, opposition to trade unionism was often a significant factor in the formation or strengthening of the company towns. Such was the case of the Ametlla de Merola company town near Puig Reig on the Alt Llobregat. Here the management response to a strike which spread from Manresa in 1890 was to reorganise. Several families were sacked, the internal structure of the town became more authoritarian, and great importance was attached to Catholic propaganda. Similarly, in 1900 , during an intense period of social conflict on the Ter, the Rusiñol company town near Manlleu opened a school on its premises, which it put in the hands of the clergy ${ }^{21}$ These towns were, in fact, steeped in conservative Catholicism, with priests and nuns employed both for compulsory religious services and to educate the workers' children.

20 See the complaints by the Alta Muntanya industrialists in La Jornada, pp. 49-50, 224.

${ }^{21}$ Ignasi Terrades, Les Colonies Industrials. Un Estudi entorn del Cas de L'Ametlla de Merola (Barcelona, 1979), pp. 155-157; El Ter, 19 May 1900. 
The largest of the company towns in the Alt Llobregat were very successful. The workforce, which was almost totally of rural extraction, lacked any tradition of collective action. Moreover, in the countryside and in many small towns the powerful industrialists and their representatives were easily able to impose their will on the local authorities. As a result they could put pressure on workers to vote for candidates of their choice at election time, and were backed up by the courts and police in cases of industrial unrest. In this way, there grew up the figure of the industrial cacique alongside the traditional agrarian cacique, of such importance in nineteenth-century Spanish history. The power of the industrialist over his captive labour force also meant that labour costs could be cut to a minimum. Indeed, up to the mid-1890s at least, many Alt Llobregat company towns did not pay wages at all, but gave their workers vouchers which had to be exchanged for goods sold within the town itself. ${ }^{22}$

The other main areas of the Alta Muntanya in which hydraulic power was extensively used were the Ter and Freser valleys. In these areas, however, the company towns were not as numerous. Nor were they as all-inclusive as in the Alt Llobregat. This difference was made clear by the leading Catalan socialist, José Comaposada. He had visited the Alt Llobregat in 1913 and gave a harrowing account of working conditions in the company towns. Yet, after a similar tour around the Ter and Freser in 1916 he stated: ${ }^{23}$

For the sake of the truth [ . . ], we must note that the company towns to which we have referred (in the Ter and Freser) are a long way from being the same as those which operate in the Alt Llobregat.

While in the latter a despicable dictatorial regime has been established, the simple thought of which infuriates the spirit, for it converts the workers into slaves in the true sense of the word, the company towns along the Ter and Freser are no more than factories set up outside the towns. They exploit the workers as do all enterprises of this type, but without the attack on human dignity reaching the incredible extremes it does in the Alt Llobregat.

One reason for this difference was that the vertically integrated weaving and spinning plants of the Alt Llobregat were considerably larger than most of those on the Ter which specialised in spinning. ${ }^{24}$ The cost of building a

22 José Comaposada, "El Movimiento Fabril", La Justicia Social [hereafter LJS], 9 August 1913, p. 2; Miguel Renté, La Abolición del Salario por la Participación en los Beneficios (Barcelona, 1899), p. 23; Miguel Izard, Industrialización, pp. 85-86.

${ }^{23}$ José Comaposada, "La Vida en La Comarca del Ter l", LJS, 4 November 1916, pp. 1-2.

${ }^{24}$ This difference in size was, at least in part, the result of technical factors. The Alt Llobregat specialised in the production of low quality standardised textile fabrics. For industrialists in this area it was cheaper to spin and weave the product in the same establishment. However, on the Ter, yarn was produced for somewhat higher quality garments which were more subject to variations in taste and hence to fluctuations in 
company town, which included housing for the whole workforce, was very high, and it was only the larger establishments that could afford such outlays. It was no doubt for this reason that in 1916, out of 76 factories to be found on the banks of the Ter and Freser, no more than 17 were in company towns. ${ }^{25}$ Furthermore, as José Comaposada noted, they were not at all similar to those on the Llobregat. The most all-inclusive was probably Fabra i Coats' spinning factory, Noves Hilatures del Ter, which was built near Torelló in the 1890 s. It was set up with English and Catalan capital, and out of a total workforce which at its high point was 500 strong, it provided housing for about 300 . The town also had a church and two schools. The paternalist relation between the employer and his men was cemented through a pension fund, free medical treatment and a consumer co-operative.$^{26}$ In fact the régime in this company town, as in two other faciories owned by Fabra i Coats on the Barcelona Pla, was highly benevolent, and the working week was shorter than in the nearby factories. This ensured that Fabra i Coats probably had the best industrial relations record of any factory in the areas under study.

However, few of the Ter Valley company towns were involved in the lives of their workforce to such a degree as Fabra i Coats. One of the basic dissimilarities between the Llobregat and Ter company towns was that only a relatively small proportion of the workers actually lived and slept in the latter. La Mambla near the town of Orís was one of the largest on the Ter. In 1914-1915 it employed 225 workers, and there was housing for 102. However, the Vilaseca company town near Torelló employed 450 workers at the same date, but housed only 62 , and the Corominas company town, also built near Torelló, had 234 workers on its payroll in 1911, but provided housing for just $70 .{ }^{27}$

The fact that many manufacturers did not set up company towns, and that those that functioned only provided housing for part of the workforce does not, however, mean that they drew large amounts of mixed workers from the surrounding countryside. There were already in the mid-nineteenth century a number of significant urban centres on the Ter, and they grew

demand. In this branch of the industry it was more economical for a factory which specialised in weaving to purchase the yarn it needed at any given moment rather than spin a large and changeable variety of yarns. The Ter Valley factories, therefore, tended to specialise in spinning alone. Angel Smith, "Industry, Labour and Politics in Catalonia, 1897-1914" (Unpublished Ph.D., University of London, 1990), p. 35.

${ }^{25}$ José Comaposada, "La Vida I', op.cit., p. 1.

${ }^{26}$ ETN, 17 July 1898, p. 35; Memoria sobre Las Obras Sociales a Favor de Los Trabajadores en La Compañía Anónima de Fabra i Coats de Barcelona (Barcelona, 1916).

${ }^{27}$ Leopoldo Negre, "Enquesta sobre les Condicions Econòmic-Socials de les Conques del Ter i Fresser", Anuari d'Estadística Social de Catalunya, 1915 (Barcelona, 1917), pp. 124-125; AMT, Estadística del Trabajo. Registro de los Obreros de Ambos Sexos que Trabajan en esta Localidad el 1911. 
rapidly as the area industrialised. Growth was most rapid in Manlleu and Roda. Thus, while Manlleu had 1,991 inhabitants in 1842, by 1900 the number had risen to 5,823. At the same time Roda increased its population from only 593 in 1843 , to 2,287 in 1900 . By 188722,862 people lived in urban areas on the Vic Plain, the heart of which was the Ter Valley. This represented about half the area's total population. ${ }^{28}$

The development of these urban centres was to be of great importance for the subsequent history of the Ter Valley labour movement. The workers did not totally break their bonds with the land. As late as 1928 many workers still owned plots of land. ${ }^{29}$ Produce from these allotments was certainly a useful supplement to the workers' industrial wage, and the possibility of turning to agricultural work also helps to explain their ability to resist prolonged strikes and lock-outs. Yet this should not obscure the fact that by the late nineteenth century in the Ter Valley towns the workers were primarily industrial. Their main source of income was wage labour, and most lived in an urban, industrial setting. Manlleu was the clearest example of this transformation, having "an essentially industrial appearance, like Sabadell, Terrassa, Mataró, and other towns of the same type". ${ }^{30}$

The importance of this point for our study is that in an urban setting workers were in a far stronger position to set up trade unions and other associations to defend their interests. Furthermore, because in the Ter and Freser part of the company town workforce also lived in urban areas, and therefore mixed with the other workers in their free time, the associations the town workers created found support throughout the region. This could most clearly be seen in the largest of these towns, such as Manlleu and Roda. ${ }^{31}$ Because of the relatively strong bargaining position of workers on

28 Joaquim Albareda, op.cit., pp. 99, 105; Guillermo Graell, Historia del Fomento del Trabajo Nacional (Barcelona, 1911), pp. 442-492; Juan Sallarés y Pla, El Trabajo de las Mujeres y Niños. Estudio sobre las condiciones actuales (Sabadell, 1892), p. 130; Leopoldo Negre, op.cit., pp. 102-150.

29 Gonçal de Reparaz (fil), La Plana de Vic (Barcelona, 1928), p. 110.

30 José Comaposada, "La Vida del Obrero en la Comarca del Ter X. Manlleu", LJS, 28 December 1916, p. 2. See also, Joaquim Albareda and Miquel Surinyach, La Industrialització a Manlleu. Energia Hidraùlica, Creixement Urba, Treballadors $i$ fabricants (Manlleu, 1987), pp. 33-38, 56-58.

31 Along the Alt Ter and around Girona, on the other hand, the task of forming stable unions and political bodies was a far more difficult task, for, in José Comaposada's words: "In spite of their best efforts it is impossible for the workers in the outlying districts to defeat the bourgeoisie single handed. The bourgeoisie has all the power which money, the church, the civil guard and the local authorities can bestow, and all the resources of state power"; José Comaposada, "La Vida, III", LJS, 28 December 1916, p. 2. Examples of caciquismo on the Ter are to be found in Joaquim Albareda i Jordi Figuerola, "Una visió de la comarca d'Osona: anàlisi del control social en una comarca d'economia dual", in Conxita Mir (ed.), Actitudes Polítiques i Control Social a la Catalunya de la Restauració, 1875-1925 (Lleida, 1989), pp. 171-190. 
the Ter, wages were higher and working hours shorter than over most of the Alta Muntanya. Indeed, consequent upon the decline in wages in Barcelona from the $1880 \mathrm{~s}$, associated with the substitution of female for male powerloom weavers, the difference between average wage rates in the Ter and the Catalan capital became increasingly narrow. Furthermore, the relatively highly paid male spinners and carders formed a far higher proportion of the cotton textile labour force on the Ter than in Barcelona. In the Catalan capital, it has been suggested, men may have made up no more than 3 per cent of the labour force. Male adults, on the other hand, represented about 23 per cent of the industry's workforce along the Ter and Freser, but in the larger Ter Valley towns this proportion was usually higher. In Manlleu, in fact, a majority of the workers appear to have been men. ${ }^{32}$

The fact that there were a relatively high percentage of male workers is of key importance for our understanding of labour protest on the Ter, for it was the men who were behind trade-union oganisation, and it was their interests that the unions were formed to defend. The workers of the Ter had only in the past generation been drawn from the surrounding peasantry, and they were still strongly influenced by the values of the peasant family economy. Throughout Europe these values were very similar. They did not oppose female labour, but stressed that it was supplementary to that of the male head of the household ${ }^{33}$ It was this notion of women's work as a supplement which allowed employers to pay women so much less than men. For this reason on the Ter male heads of household had been given higher paid work as spinners while women were employed in the low paid preparatory processes. It was a sexual division of labour of which, all evidence suggests, the men approved. ${ }^{34}$ Within the peasant family economy daughters were expected to work full time. However, once a woman was married her primary role was seen as in the domestic sphere. These values were also passed on to the first generations of Catalan proletarians. The result was

\footnotetext{
${ }^{32}$ Miguel Sastre, Las Huelgas en Barcelona, pp. 12-13; Leopoldo Negre, op.cit., p. 106. From the late nineteenth century through to 1914 working hours in Barcelona cotton textiles were 64 per week. In the Ter Valley they were officially 66 for day and 48 for night work, though they were in reality somewhat longer as workers were expected to take turns and mind each others machines during lunch and dinner breaks. Throughout most of the Alta Muntanya, however, working hours were considerably longer. In the Alt Llobregat a 70-hour week was the minimum. For more details on wages and working hours see Angel Smith, "Industry, Labour and Politics in Catalonia", pp. 40-41.

${ }^{33}$ Louise Tilly and Joan Scott, "Women's Work and the Family in Nineteenth Century Europe", in Charles E. Rosenberg (ed.), The Family in History (Philadelphia, 1975), pp. 151-177.

34 Thus the cotton textile industrialists correctly noted that male workers would not take employment in the preparatory processes "because they regard it as improper of the male sex". Boletín de la Industria y Comercio de Sabadell, May 1911. It was also for this reason that male workers would often complain at the employers' attempts to pay them a "woman's wage".
} 
that most female workers tended to be yound and unmarried. It was for these reasons that the cotton textile spinners were so outraged by the industrialists' attempts to replace them by women on the ring-frames. Their attitude could clearly be seen in 1911 when the Ter Valley unions launched a campaign in support of a government bill to abolish female night work. This the unions claimed was necessary "given the debility of the female sex", and they made no secret of the hope that: ${ }^{35}$

With the introduction of the said law hundreds of unemployed men will find work and they will, therefore, cease to be half women (hombres mujeres) dedicated to domestic chores, which are a woman's preserve. With this work they will be the family's bread winners, while their women will be able to stay at home and really carry out the sacred duties of a mother and wife. This does not happen at present due to the distribution of work in the factories.

Indeed, the radical nature of this critique of female factory work suggests that the male workers had at least partly accepted the liberal view that there should be a total separation between work and the domestic sphere. In the cotton textile industry conflict over wages and working hours were common. Nevertheless, on the Ter the most bitter fought industrial disputes were to revolve around the employers' efforts to replace male by female workers.

\section{Social conflict and labour politics}

In the cotton textile industry the first unions were formed in the 1840 s and 1850s. However, because of state repression the workers found it difficult to organise effectively. It was not until the so-called "Democratic Six Years" (Sexenio Democrático) between 1868 and 1873 that union organisation grew rapidly. The attitude of most employers was hostile. Nevertheless, in urban areas it proved difficult to halt the advance of trade unionism. Fierce competition between industrialists hampered attempts to collaborate in the formation of federations aimed at combatting trade unionism. Moreover, between 1869 and 1883, as has been seen, the cotton industry expanded rapidly and profits were high. This provided industrialists with an incentive not to provoke costly disputes.

In 1868 a Catalan-wide cotton textile labour federation was founded. This federation was called the Three Steam Sections or Tres Classes de Vapor (TCV) because it aimed to organise workers in the preparatory, spinning and power-loom weaving branches of the industry. From the outset it was centralised in Barcelona and developed rather a bureaucratic

${ }^{35}$ AMT (A), C. Asociaciones S. - de 1910 a.... Gran Mitin Monstruo en Torelló. 
structure based on paid officials. It also adopted a very moderate tradeunion practice. Its main aim was to bring wage rates outside Barcelona up to the level of those in the Catalan capital. This policy was cautiously pursued. All efforts were made to reach a negotiated settlement to disputes, and strikes were only declared in the last resort. The TCV was forced underground after the fall of the First Republic. However, it was again to flourish in the more open atmosphere of the years 1881-1883. In this latter year it had about 20,000 members, over a quarter of the region's cotton textile labour force. ${ }^{36}$

As a result of the TCV's success then, there grew up a body of officials who by the early 1880 s consciously modelled their policy on that of the reformist leaders of the English "New Model Unions". Some employer representatives came to support the TCV officials' goal of peaceful collective bargaining within the framework of capitalism. From 1889 most cotton textile industrialists formed part of an employer organisation called the Foment del Treball Nacional (FTN). The Foment, as it came to be known, was by the end of the nineteenth century the most important employer organisation in the country, and its prestigious monthly publication, $E l$ Trabajo Nacional, had a very wide circulation. El Trabajo Nacional was first published in 1895 and from the start the contributors showed themselves to be in favour of union organisation. They argued that by accepting the right of unions to exist and giving them legal guarantees they would be taken out of the hands of extremists, and that once responsible leaders were elected it would be easier for employers to solve disputes than if they had to deal with a non-unionised amorphous working-class mass. ${ }^{37}$

By the end of the nineteenth century, however, this was by no means the dominant view amongst the cotton masters. Many employers had always been deeply suspicious of trade unionism. From the mid-1880s the cotton industrialists took an increasingly belligerent stance. The principal reason appears to have been economic. As we have seen, it was during these years that the economic climate in Catalonia became markedly more adverse. Cotton textile industrialists responded by cutting wages and by restructuring the labour process in their favour. In rural areas, where the company towns operated, this was a relatively easy task. The workers were able to offer little resistance to the omnipotent industrial caciques. In the towns, on the other hand, workers put up a stauncher fight, and for this reason

${ }^{36}$ Miguel Izard, "Entre la Impotencia y la Esperanza"; Industrialización, pp. 11-12, 120-129; Ramón Casterás, Actitudes de los Sectores Catalanes en la Coyuntura de los Años 1880 (Barcelona, 1985), pp. 43-100; F. Dalmases Gil, El Socialismo en Barcelona (Barcelona, 1890), pp. 12-14; Manuel Reventós, Assaig sobre alguns Episodis dels Moviments Socials a Barcelona en el Segle XIX (Barcelona, 1925), pp. 157-159.

${ }^{37}$ See, for example, ETN, 1 November 1907, pp. 521-522; 16 September 1909, p. 291; 16 May 1911, pp. 213-214; F. Rahola y Tremols, op.cit., pp. 365-366; Joaquín Romero Maura, La Rosa del Fuego: el obrerismo barcenolés de 1899 a 1909 (Barcelona, 1975), pp. $429-431$. 
industrialists had to break the back of trade unionism in the industry in order to impose the new working conditions.

The employer offensive began in Ripoll and Campdevanol on the Freser river, where in 1889 local industrialists were able to destroy trade-union organisation and impose harsher working conditions. ${ }^{38}$ The offensive continued in Manresa in the following year. In the Manresa area, unlike the Ter and Freser, power-loom weaving predominated, and the labour force was by this time to a large extent female. The industrialists' main aim was, therefore, to cut costs at the expense of the female weavers and preparatory workers. In order to pursue this objective they took advantage of a disagreement over wage rates to lock out the entire labour force. There then followed solidarity strikes in Barcelona and the surrounding towns, which according to some estimates affected up to 50,000 workers. In Manresa the workers achieved a temporary victory when the civil governor forced the town's industrialists to end their lock-out and enter into negotiations with the workers. The victory was, however, to be short-lived. In July 1891 the Conservatives replaced the Liberals in power. The Conservative Party had forged close links with the Catalan industrial bourgeoisie. The Manresa and Alt Llobregat industrialists, therefore, took advantage of the new political conjuncture to close their factories throughout the region and sack large numbers of workers. In Manresa the TCV declared a general strike in response to the sacking of its factory delegates. Several days later it was pressured into declaring a solidarity strike in Barcelona. Its actions were, however, all to no avail. In Manresa and industrial towns throughout the Alt Llobregat the workers were defeated and their trade unions outlawed. ${ }^{39}$

The workers of the Ter Valley were to face the employer onslaught in 1891. The employer drive to cut costs on the Ter was to lead to bitter and protracted industrial conflict, for within the cotton textile industry it was the workers of the larger industrial towns on the Ter who were best able to defend their interests. In part, as we have seen, this was a result of the fact that in an urban environment a sense of community could be built up, and trade unions established far more easily. Furthermore, there was a relatively high proportion of male workers. Particularly important in this respect were the spinners, who formed the backbone of the Ter unions. As has been noted, they were skilled workers, and because they were able to limit the recruitment of piecers onto the self-acting mules they maintained a strong position on the shop floor. In the 1880 s for the first time industrialists moved to replace them with female workers on the ring-frames. However,

${ }^{38}$ ES, 8 November, 6 December 1889.

${ }^{39}$ On these strikes see, Miguel Izard, Industrialización, pp. 167-172; Joaquim Ferrer, El Primer "ler de Maig" a Catalunya (Barcelona, 1972), pp. 61-68. 
the spinners were able to respond by mobilising the whole of the cotton textile labour force behind their demands.

The relative strength of labour in the main Ter Valley towns initially led industrialists to adopt a cautious approach. In most areas, mill owners who introduced the ring-frame immediately tried to replace the male spinners by female workers on these machines. Yet, according to "R.S" the correspondent of the republican daily La Publicidad, in Manlleu: "When the first machines known as ring-frames were introduced a gentleman's agreement was reached to the effect that they would be worked by men, and that of the profits that resulted from the new machinery two-thirds would be for the industrialist and the rest for the worker". ${ }^{40}$ However, as the economic crisis deepened the Manlleu employers became increasingly dissatisfied with this accord.

The first serious attempt to replace men by women on the ring-frames was made in 1891 . The first step taken by the employers was to found the Foment Moral $i$ Material, which was to act as a co-ordinating body of all the town's industrialists. The employers' strategy was then to provoke a conflict, destroy trade-union organisation in the industry, and finally impose the new working practices. Their action began in October when five female frame-tenters were sacked from the factory of Rifa i Co. for no apparent reason. In response, the rest of the town's workforce came out on strike in solidarity. The reaction of the Manlleu employers could not have been more drastic. They locked out the town's entire workforce and stated that work would not resume until Rifa i Co. had restarted production without the five women. As a result, not surprisingly, the workers adopted an increasingly radical stance. In October 1891 the Manlleu textile unions were described as "always moderate and without utopian demands". Yet, in a leaflet published on 19 November the Manlleu Workers' Commission talked of a fight to the death between the exploiters and exploited. ${ }^{41}$

On this occasion the cotton textile industrialists were not to be successful. The workers had public opinion on their side and collected large amounts of money. They were, therefore, able to resist the lock-out relatively well. Consequently, on 12-13 December the industrialists agreed to a compromise solution which in no way fundamentally affected the position of the

40 La Publicidad [hereafter LP], 14 October 1891. He continued: "This to my mind is the only way to resolve these social questions, and is very different from the stance generally taken (by the employers) in Catalonia, which leaves the men without a job".

${ }^{41}$ LP, 14 October 1891; ES, 23 November 1891. The real motives behind the lock-out were pin-pointed by the correspondent of La Publicidad, who stated: "It seems that some intransigents, spurred on by the results of the conflicts in Ripoll, Manresa and the Llobregat, want to make a last ditch stand and subject their workers to the same conditions as in the factories in these towns. That is to say to break their old customs." These were, he added, the agreements that men should work the ring-frames and that no worker could be sacked without a justifiable reason. LP, 1 November 1891. 
spinners within the labour process. The end of the Manlleu lock-out was an important victory in the context of the string of defeats which had recently been inflicted on the cotton textile workers. Yet the victory of the male spinners had only been partial. They had maintained their position in Manlleu and to a certain extent in the nearby towns of Roda and Sant Hipolit. This fact confirmed that these were the strongest points of working class resistance in the area. It did not, however, prevent the employers from replacing men by women in the other Ter and Freser towns, not to mention the Alt Llobregat. ${ }^{42}$

Furthermore, the Manlleu victory was insufficient to halt the general collapse of trade unionism in the cotton textile industry. In the repressive climate of the 1890 s this pattern would be very difficult to reverse. The TCV was almost totally destroyed in the employer offensive of the years 18891891 , and over the next eight years trade-union organisation in the industry remained very weak. Industrialists were, therefore, able to take advantage of this situation further to cut wages, lengthen working hours, and replace male by female labour.

The employer offensive against the TCV also had wide ranging political consequences. During the 1880 s there had been an important reformist element within the Catalan labour movement. The TCV was the fulcrum around which reformist politics revolved. However, as a consequence of the industrialists' attack on the cotton textile trade unions between 1889 and 1891, the position of the reformists within organised labour was greatly weakened. Between 1885 and 1890 the TCV leadership had not reacted to the employers' increasingly threatening stance by staunchly defending its members' interests. Instead it had become markedly more class collaborationist, and not only supported the industrialists' call for higher duties on imported textile fabrics, but also seconded demonstrations organised by the industrialists to bring pressure to bear on the authorities in this respect. The attitude of the TCV leaders brought the federation's credibility into doubt, and in the aftermath of the employer offensive other political groupings, disgusted by the TCV's collaborationist policies, founded their own textile federations. The anarchists set up a Pacte Lliure in the early 1890 s, which gained some support in Barcelona and the Ter Valley. It was, however, soon to founder. Members of the Spanish Socialist Party (PSOE) had rather more success. They founded their alternative to the TCV, the Unión Fabril Algodonera, in 1894, and textile unions from Sant Martí, the Ter Valley, Mataró, Vilanova and Vilassar affiliated..$^{43}$

${ }^{42}$ LP, November-December, 1891; José Comaposada, “La Vida, X”, op.cit., pp. 1- 2. ${ }^{43}$ Juan de Cataluña (pseudonym of Joan Codina), "Los Obreros de la Industria Textil III", La Justicia, 19 February 1930, pp. 3-4; Santiago Castillo, "Los Orígines de la Organización Obrera en España: de la Federación de Tipógrafos a la UG de T", Estudios de Historia Social, 26-27 (1983), pp. 102-104; La República Social, 3 March 1897, 12 
Nevertheless, because of the overall weakness of the Catalan textile unions during the $1890 \mathrm{~s}$, it was only at the end of the decade that it became apparent that there had been a general shift in the political complexion of the textile unions. In 1899, despite the loss of the colonies in the previous year, there was a short-lived economic boom in the industry. Demand was stimulated by exceptional harvests, and the need to clothe repatriated troops. ${ }^{44}$ At the same time government repression of labour in Catalonia eased significantly. It was the combination of these two factors which made possible the rebirth of trade-union organisation. It was Manlleu and the principal Ter Valley towns that were at the forefront of this recovery. In Manlleu the 1891 pact not to use female labour on the ring-frames had only begrudgingly been accepted by the employers, and was, therefore, a source of constant tension. During 1897-1898 the employers called the pact increasingly into question, and in line with industrialists in the rest of Catalonia they continuously chipped away at established work practices. In 1898 , however, the Manlleu workers formed a new union, which was to grow rapidly in the following year. As a result the workers were able to launch a counteroffensive against the mill-owners.

In February 1899 the new union called a general strike in defence of the 1891 pact. This action forced the employers on the defensive, and after a few days they agreed to accept the workers' demands. ${ }^{45}$ This victory gave a great boost to trade-union organisation throughout the Ter. At the beginning of March general strikes were declared in Torelló and Vic, with solidarity strikes by the workers of two factories in Roda. After a long and arduous struggle the strikes finally ended in success, and wage increases were accepted in all of the factories. Just as important, it was also agreed that when spinning machines became vacant or new machines were installed they would in the future be operated by male workers. ${ }^{46}$

The events of these months confirmed the collective strength of labour in the larger Ter Valley towns. The towns' textile labour force almost unanimously seconded the disputes. This included workers from the area's larger company towns. Female workers also came out in support. This is an important point to note, for although the strikes often involved claims for pay increases, the main underlying cause of tension was the employers' wish

January, 20 April 1898.

44 R. J. Harrison, "Catalan Business and the Loss of Cuba", Economic History Review, 2nd series, XXVII (August, 1974), pp. 434-435.

${ }^{45}$ ES, 14 January, 25 February 1898, 24 February 1899; El Ter, 18 December 1897, 25 February 1899; LP, 17 February, Morning Edition [hereafter ME], 20 February, ME, 1899.

${ }^{46}$ Juan de Cataluña, "Los Obreros de la Industria Textil IV. Continua el Relato", La Justicia, 26 February 1930, p. 2. That the workers intended the agreement to be honoured was shown later in the year in Torello, where a strike was called in the Colomer factory after a woman had been employed on a ring-frame. ES, 29 September 1899. 
to replace male by female workers. Male and female textile workers, it should be remembered, formed part of the same families. Women textile workers, therefore, seem to have accepted the view that the male head of the household should be the main breadwinner, and that female labour was only supplementary. This vision was no doubt reinforced by the more prosaic consideration that if the male spinners were made redundant the income of the whole family would decline.

The support received by the strikers was not, however, limited to the working class. In these towns it embraced virtually the whole community. Particularly important in this respect was the attitude of the towns' petty traders, who proved willing to sell the workers food on credit. These tradesmen were almost totally dependent on the workers for business. They could therefore readily sympathise with the strikers' opposition to cuts in their standard of living. These ties were strengthened by the fact that most of the larger-scale industrialists in the area lived in Barcelona, and left the running of their factories in the hands of managers. Consequently, they did not build up personal contacts with the townsfolk, and could be seen as outsiders who damaged the local community's prosperity through their actions. Finally, the 1899 strikes were also aided by the benevolent stance adopted by the province's civil governor. His attitude was probably not unrelated to the fact that after the loss of the last colonies many cotton textile industrialists began to distance themselves from the Restoration state's official parties. Through its actions it seems that the Government wished to frighten them back to the fold. ${ }^{47}$

After their victories the Ter Valley trade-union leadership began to look further afield, and planned a recruitment drive through Girona and the $A_{\imath} t$ Llobregat. In order to coordinate their efforts the unions formed a district federation known as the Commission for the Fourth District and appointed a full-time official to run day-to-day business. The first fruit of this drive was the extension of union organisation to the more outlying areas of the Ter and into the Freser Valley ${ }^{48}$ The Ter and Freser Valleys were not, however, the only points in Catalonia in which there was a resurgence of trade unions. In Manresa, where all organisation in the industry had been destroyed in 1890 , there was also a parallel growth. ${ }^{49}$

${ }^{47}$ On this point see, Juan de Cataluña, "Los Obreros de la Industria Textil IV", p. 2.

48 Particularly important in this respect was the case of Ripoll which had a large workingclass population. A new union was formed in the town in August 1899, and the employers were almost immediately presented with a demand for improved wages and working conditions. The strike which followed met with success, and an accord was signed which stipulated not only an increase in wages, but also that, "the means by which the personnel on the ring-frames might be changed, occupying them with men, will be subject to study". ES, 29 September 1899.

${ }^{49}$ ES, 10 February, 10 March 1899. 
This union revival crystallised in the Autumn of 1899 with the foundation of a new regional textile labour federation. Within the Commission for the Fourth District there was a significant anarchist presence. Nevertheless, a delegation from the Fourth District attended the Sixth congress of the small Socialist Unión Fabril Algodonera, held in Mataró between 5 and 6 August, informed those present that it was considering calling a congress open to all the industry's workers, and asked the socialists to lend their support. Their reaction was favourable and, as a result, a commission made up of representatives of both the Unión Fabril Algodonera and the Commission for the Fourth District was set up to organise the founding congress. This compromise reflected the fact that no political grouping was by itself strong enough to set up a unified regional federation. The attitude adopted by the socialists allowed the new organisation quickly to establish itself. Its founding congress was held in Barcelona between 8 and 10 September 1899. At this congress it was agreed that the federation should be called the $\mathrm{Fe}$ deración de la Industria Textil Española (FTE), that its central committee should reside in Manlleu, and that it should have its own publication entitled Revista Fabril. . $^{\text {so }}$

In two respects the FTE represented an important break with the past. In the first place, it was decided to set up the FTE's central committee in Manlleu rather than Barcelona, which had been the seat of the TCV leadership. This break reflected the fact that since the mid-1880s it was the Ter Valley unions that had most successfully been able to defend their workers' interests. Since the 1870 s many spinning factories moved from Barcelona to the Alta Muntanya river banks. Moreover, those mill owners who stayed in Barcelona had been able to replace the lesser skilled male by female power-loom weavers with relatively little difficulty. It was these male spinners and power-loom weavers who had been in charge of the TCV. With their departure, therefore, an increasingly large percentage of the cotton textile labour force was female, and these female workers found it very difficult to unionise. Hence the weakness of trade-union organisation in Barcelona at this time.

This basic shift in the geography of Catalan textile trade unionism became clear in the following year. At the time of its foundation the federation had about 7,000 affiliates, so its first priority was to extend its membership. In order to carry out this objective recruitment drives were made throughout the region in the following months. The result of this activity could be seen at the FTE's second congress held in Manresa between 29 June and 1 July 1900 . There were 84 delegates from 34 localities present. It was claimed that they represented the no doubt exaggerated figure of between 50,000 and 70,000 affiliates. Trade-union organisation

${ }^{\text {so }}$ LP, 11 September 1899, ME. 
was still centred on the larger Ter Valley towns and the Llobregat around Manresa. Nevertheless, it had also made significant headway in the Alt Llobregat and on the Ter around Girona. In the Ter Valley towns themselves union organisation was now very strong. In Manlleu, for example, it was impossible to find work without being unionised. Barcelona, however, remained a black spot. Despite the growth of union organisation in much of the industry the female power-loom weavers had found it impossible to follow suit. Thus the TCV rump had only 250 members and other textile unions in the city were equally weak. ${ }^{51}$

However, geographical location was not the only difference between the old Catalan-wide TCV and the FTE. There was also a marked contrast between the two federations' political make-up. The remnants of the TCV affiliated to the FTE and exercised some influence. Yet TCV sympathisers were now in a minority. The anarchists maintained their presence in the Ter Valley. Nevertheless, in 1899 and 1900 it was the Catalan socialists who were in the strongest position within the FTE. Hence the fact that the leading Catalan socialist, Toribio Reoyo, was director of the federation's mouthpiece, Revista Fabril, and that the socialists were the most regular contributors to its pages. ${ }^{52}$

Because of the anarchist and socialist presence, the FTE adopted a more combative stance than its predecessor. At the same time, however, it structured itself along lines similar to those of the TCV. Thus, its General Secretary and President were paid officials. The Federation was divided into eight different districts each covering a part of Catalonia, and full-time officials were also appointed in each of these areas. The FTE pursued two basic aims. The first was to reverse the trend in the industry towards the substitution of male by female labour. ${ }^{53}$ Its second aim was to improve wages and working conditions. Like the TCV it aimed to secure wages and working hours in the area in which working conditions were best and then try and bring conditions in other areas up to the same level. By 1900 , however, it was in Manlleu that unionised workers were paid the best rates.

This strategy was, however, soon to run into difficulties. Workers had not been able to express their discontent for a number of years and so there was a great feeling of pent-up anger and frustration. There was, therefore, a tendency for many workers to go on strike immediately they had begun to

${ }^{51}$ LP, 11 September, ME, 18 October, ME 1899, 5 July, ME, 1900; Revista Fabril, 7 June, 5 July 1900; La Plana de Vich, 1 August 1900.

${ }_{52}$ Revista Fabril, 20 April, 5, 12 and 19 July 1900.

${ }^{53}$ This became official policy at the federation's second congress, at which a delegate from Vic presented a motion which asked: "Is it advisable that as the spinning machines and power-looms become vacant they be occupied by men over fourteen years of age?" He stated that in his town this policy had been implemented and was a great success. The motion was then put to the vote and approved unanimously. Revista Fabril, 5 July 1900. 
organise. At the same time, in the textile towns, industrialists who had grown accustomed to dominating the affairs of the locality were loath to accept a weakening of their grip. The result was a rapid escalation of industrial conflict. Thus, for example, from October to December 1899 there were at least twenty strikes or lock-outs in the industry. In these circumstances the FTE central committee began to fear that the whole organisation might collapse. It therefore counselled prudence in the declaration of strikes, and formed a commission to try and reach a negotiated settlement of those disputes in progress. ${ }^{54}$ Such a moderate course was not only favoured by affiliates to the TCV. Despite their strict class analysis of society the socialists also laid stress on the need for negotiation and compromise. Like the TCV in the 1880s, then, the FTE was trying to establish formal collective bargaining procedures with the employers.

This was, however, once again to prove impossible. While the economic conjuncture remained favourable the FTE could continue to expand. The conjuncture, however, was dramatically to change in the summer of 1900. The industry was faced with the full impact of the loss of the colonies at the same time as the price of raw cotton rose steeply on international markets. Consequently another severe economic recession hit the industry. ${ }^{55}$ This led to a rapid rise in unemployment. Furthermore, as the economic recession deepened so industrialists throughout Catalonia, their profit margins once again under threat, prepared to strike back against the FTE. In the Ter their first reaction to the challenge of labour had been to build up their own organisations. The Manlleu employers had already associated in the late 1890s. The mill owners of Vic and Roda followed suit in the Summer of 1900, and, according to La Plana de Vich, by the Autumn of that year: "Fifty nine of the sixty three Ter industrialists have associated and in the future they will not allow delegate inspectors from the Workers' Association into their factories". ${ }^{56}$

The first sign of an impending employer onslaught came at the beginning of 1900 , when after unsuccessful negotiations over new wage rates a lockout was declared throughout the length of the Freser river. In all about 5,000 workers were left on the streets. Although the dispute was primarily over wages, conflict over the attempt made by the FTE to reverse the

\footnotetext{
${ }^{54}$ Revista Fabril, 7 and 28 June, 1900.

${ }^{55}$ Conditions were to improve little in forthcoming years. 1902 saw a poor harvest in Castile. Then, between 1904 and 1905, the whole of Spain suffered an agrarian depression. R. J. Harrison, "The Spanish Famine of 1904-1906", Agricultural History, Vol. XLVII (1973), pp. 302- 310.

${ }^{56}$ La Plana de Vich, 8 August 1900. By this time there were four employer associations in the Ter and Freser: Manlleu and District, Vic-Roda, Alt Ter and Freser, and Torelló and Sant Quirze.
} 
substitution of male by female spinners on the ring-frames was never far below the surface. ${ }^{57}$ The lock-out was to last for four months with work not resuming until 15 May. Nevertheless, the trade unions remained solid, and work did not finally resume until the mill owners had agreed to re-employ all sacked workers.

The lock-out, therefore, highlighted the determination of the Ter and Freser workers to resist their employers' demands. Nevertheless, in the following months tension continued to mount. This is illustrated by the fact that employers began to use increasingly anti-union rhetoric. For example, the president of the Alt Ter $i$ Freser employers' association, though recognising the economic factors behind the recession, maintained that wage costs were higher in Catalonia than in any other part of the world. He also accused the workers of ignorance because they had opposed the introduction of new machinery, and claimed that this attitude was the root cause of the technological backwardness of Catalan industry. Finally, he accused the Government of exacerbating industrial conflict by favouring the workers' demands. Clearly this represented a call on the Government to support the employers' forthcoming attack on the unions. Josep Ma Prat i Vilaró, president of the Manlleu i Comarca employers' association, however, went further. He maintained that had it not been for the large number of strikes in the industry the loss of the colonies would have had absolutely no impact, and his reply to the question of how "class harmony" could be restored in the industry was a battle cry to the region's mill owners. Thus he stated: "It could be achieved by making the principle of authority respected. Today the workers use brute force. They have become emboldened." 58

Workers' representatives, on the other hand, claimed that the industrialists' greed was at least partly responsible for the crisis. Josep Genollà, president of the FTE from August 1900, argued that the solution to the recession lay in the reduction of working hours and a rise in the price of textile fabrics to offset the increasing cost of raw material imports. He also stated that to maintain the workers' purchasing power an increase in wages would be necessary. At grass roots level it seems the view that the mill owners had provoked the economic recession was widespread. Although Genollà refused to comment, therefore, the belief was growing amongst the workers that if nothing were done to alleviate the crisis strike action would be necessary. ${ }^{59}$

57 Thus "A Worker" declared in La Publicidad on the real motives behind the employers' actions: "As the Textile Federation tends to regulate these machines [i.e., the ring-frames] it is not surprising that the industrialists try by all means at their disposal to destroy the workers' organisation". LP, 6 January 1900, ME.

${ }_{58} \mathrm{LP}, 18$ and 19 October, ME, 1900.

${ }^{59} \mathrm{LP}, 9$ and 22 October, ME, 1900. 
This attitude favoured the anarchists who, unlike the socialists and reformists, believed that in order to defeat the bourgeoisie militant direct action tactics were needed. Such tactics, the anarchists hoped, would culminate in a revolutionary General Strike, aimed at overthrowing capitalism. An all-out conflict in the industry was precipitated in November. In Manresa the mill owners provoked 3,000 textile workers into taking strike action by sacking their trade-union leadership. They followed this measure up with the introduction of good conduct certificates. In the future no worker was to be taken on unless he was recommended by his previous employer. At the same time there were widespread sackings in Ripoll and on the Ter around Girona. In Manlleu the union presented a new wage list and, after it had been rejected, went on strike on 19 November. This decision proved to be a serious tactical blunder. The mill owners were confident of their strength and so reacted by sacking the entire Manlleu workforce. Accordingly, by the end of the month much of the FTE's membership was either on strike or locked out. The workers' position was, in addition, made more difficult by the fact that the Conservative Government changed its previous stance, and decided fully to support the employer offensive. Accordingly, it reacted to the disturbances by sending large numbers of troops and civil guards into the textile towns. Furthermore, large numbers of workers were imprisoned - including the central committee of the FTE -, union headquarters were closed down, and the working class press found it difficult to publish. Revista Fabril, for example, was forced to suspend publication, never to reappear. ${ }^{60}$

In response, despite socialist opposition, the FTE attempted to organise a solidarity strike of the entire Catalan working class. The strike appears to have been followed throughout much of the Alta Muntanya. In Barcelona, however, it had no impact. Consequently, the general strike was a failure, and the back of the FTE was broken. The employer onslaught, nevertheless, continued unabated. In a meeting of mill owners at the Barcelona headquarters of the FTN it was agreed not to employ those workers most identified with the unions. This decision became known as the "hunger pact". The result was that about 800 workers were sacked and in order to find work in a Catalan cotton textile factory had to hide their real identities. ${ }^{61}$

This attack on the unions was combined with moves to intensify production and restructure the labour process. In Manresa, where union organisation had been totally destroyed, no men were readmitted into the

${ }^{60}$ On the repression see, El Trabajo, 14 December 1900; ES, 23 November 1900.

${ }^{61}$ José Comaposada, "La Vida del Obrero", op.cit., X, p. 1. For Socialist criticism of the general strike see, ES, 14 December 1900, 8 February 1901. 
factories. Along the Llobregat efforts were made to increase the number of ring-frames each female spinner minded. ${ }^{62}$ These moves were largely successful. In the Ter Valley, however, the workers put up a stiffer resistance. During 1899 and 1900 the male spinners had succeeded in halting and even reversing the employer drive to replace them with female workers. The employers now looked to press ahead with their plans to employ women on the ring-frames. Conflict over this question flared up in 1901 in Roda when three factory owners tried to replace three male spinners, whom they had previously sacked, with women. The women's refusal to operate these machines led to a further lock-out in the town in March. Moreover, the Ter and Freser valley employer associations again threatened to extend the lock-out to all their factories if the Roda mill-owners' demands were not met.

The workers of Roda refused to climb down and the new lock-out, therefore, began on 11 March. As the Junta of the Manlleu textile union, the Art Fabril $i$ Anexos, stated several years later it had been called: "Because it was planned to substitute the men who worked and still work on the ring-frames by women". ${ }^{63}$ Yet, as the quotation suggests, things did not go according to plan for the industrialists, for it was as a result of the March lock-out that social conflict on the Ter burst into violence. In Torelló, on the same day as the factories were closed, a group of workers set fire to the house of the ex-Mayor and factory owner, Antonio Mercadell. In a subsequent clash with the mossos d'escuadra (local police) several workers were injured. In Ripoll a demonstration of cotton textile workers ended in clashes with the Civil Guard. On this occasion the crowd was fired upon with the result that one worker was killed and two critically injured. The most dramatic events, however, took place in Manlleu. Here the workers organised an attack on the local employers' casino or club, and injured three of those inside. The crowd then attacked the houses of the Mayor and two more industrialists, setting them all on fire. The size of the crowd made it impossible for the Civil Guard to control. Luckily its commander adopted a conciliatory stance and avoided bloodshed. Order was, nevertheless, only restored when the local authorities promised to do everything in their power to find a solution to the conflict and obtain the reinstatement of the workers subject to the "hunger pact". ${ }^{64}$

62 El Progreso, 26 October 1909.

${ }^{63}$ El Progreso, 10 July 1909.

${ }_{64}$ La Plana de Vich, 14 March 1901. The various reports of these events stressed the role played by working-class women. Thus according to one correspondent: "Amongst the rioters who committed those outrages a multitude of women were to be seen, especially in Manlleu. No doubt they threw themselves onto the public footpath on seeing that they had nothing to give their children, and that the strike imposed by their bosses had shut out any hope". La Plana de Vich, 21 March 1901. 
With these events class hatred had reached a point difficult to surpass. The situation in the Ter Valley was now extremely explosive and another outbreak of violence was feared. Tempers were, nevertheless, cooled by the replacement of the Conservative civil governor in the run up to the Liberal victory in the elections held on 19 March 1901. The new civil governor adopted a far more even-handed approach. Thus he chaired discussions between employers and workers in which he put pressure on the industrialists to reopen their factories. A compromise solution was then reached. On the one hand the employers agreed to end their lock-out and revoke the hunger pact. On the other hand, their right to employ women on the ring-frames was recognised. ${ }^{65}$

The factories finally reopened on 18 March. Amongst the workforce there was considerable discontent at the compromise reached, as it was felt that employers would now have a free hand to employ female labour. The feeling of betrayal became more intense when it emerged that few of the workers subject to the "hunger pact" would actually be reemployed. The workers' fears were, however, in some areas not to be realised. Along the upper Ter and Freser, and even in Torelló, unions had been totally destroyed, and in these areas women were employed on the ring-frame. This left Manlleu, Roda and Sant Hipòlit as the only towns on the Ter where unions continued to function. In these towns, taken aback by labour's reaction to the March lock-out, and still unable totally to outlaw the unions, mill owners still did not dare to try and replace the male by female spinners. They, therefore, became the only areas in the Alta Muntanya which continued to employ large numbers of adult male ring-frame spinners. ${ }^{66}$

In Manlleu, shocked by the events of this year, the employers tried to stabilise labour relations by setting up an industrial tribunal and friendly society. All those workers who left their union and joined the friendly society - which, it was hoped, would eventually provide old age pensions were given the right to negotiate wages and working conditions. The aim of the industrialists was to create a "conservative stratum" of workers, who would not belong to independent unions, and who would be tied to their employers by the benefits they received. The reaction of most of the Manlleu workers was, however, hostile. Consequently, the friendly society only recruited between 150 and 200 workers, and most of these came from the Rusiñol company town just outside Manlleu, where working conditions were amongst the best on the Ter. The power of the spinners on the shop floor had not been broken, and they retained the capacity to act decisively

${ }^{65}$ La Plana de Vich, 28 March 1901. These negotiations had another favourable result for the workers. Serious disagreements between the mill owners led to a weakening of employer organisation on the Ter. Juan de Cataluna, "Después del Pacto del Hambre VI", La Justicia, 15 May 1930, p. 2.

66 La Guerra Social, 18 July 1903. 
against any attempt to cut wages or threaten their position in the workplace. The employer-sponsored friendly society was, therefore, very unstable. This became clear in 1909 when the Manlleu cotton masters again tried to cut their labour costs. The spinners mobilised in opposition and, as a result, the class-collaborationist friendly society was swept away. ${ }^{67}$

Until the end of the decade, however, trade-union organisation in cotton textiles remained very weak. It was not until 1908 that the trade unions began to reorganise, and it was once again workers in the Ter Valley who led the way. In others parts of Catalonia the cotton textile workers found it more difficult to unionise. Nevertheless, the possibility of extending trade unionism was given a boost when in September 1908 a new regional labour federation, known as Solidaritat Obrera, decided to launch a recruitment drive in the industry. This drive finally began in April of the following year, after an assembly of textile workers had met in Barcelona and agreed to lay the foundations of a new Catalan textile federation. In the Alta Muntanya union organisers had little luck outside the Ter and Freser. However, unions began to spring up in a large number of urban centres around Barcelona. ${ }^{68}$

Since 1901 unemployment in the textile industries had been high. Not surprisingly, then, the April assembly decided that its first priority would be to reduce working hours in the industry. Any action the planned federation might take was, however, pre-empted by the employers. Once again, as during 1899 and 1900, the mill owners responded to the growth of tradeunion activities by opposing labour's demands, and in many cases the right of the workers even to form trade unions. Indeed, the industrialists' resolve to oppose union organisation was strengthened by the fact that the economic conjuncture actually deteriorated between 1908 and 1909 . The result was another escalation of industrial conflict from late 1908. Once again, moreover, it was a dispute in the Ter Valley that was to have the most far reaching consequences.

On the Ter employers had, as in the 1890s, taken advantage of the weak state of the unions to cut wages. Spinners were, in particular, seriously affected. The male spinners of Manlleu, Roda and Sant Hipolit nevertheless continued to earn far higher wages than female minders employed on ring-frames in the rest of the Alta Muntanya. Though the industrialists in

${ }^{67}$ On the Manlleu friendly society see, Albert Rusiñol, Bases para la Creación y el Funcionamiento de los Jurados Mixtos en Manlleu-Proyecto de Montepío reductado por D. Federico Rahola por Encargo de la Junta de Conciliación - con un Prólogo de D. Joaquín Aguilar (Barcelona, 1902); Asociaciones de Fabricantes del Ter y del Freser, Los Jurados Mixtos en España. Datos y Consideraciones Acerca de la Conciliación y el Arbitraje en los Conflictos entre Patronos y Obreros (Barcelona, 1902); AMM, Governació S149, A 395, El Productor, 26 October 1901; La Guerra Social, 4 July 1903.

${ }_{68}$ El Trabajo, 23 May 1908; Solidaridad Obrera [hereafter SO], 4 December 1908; La Internacional, 5 February 1909. 
these towns had been forced to abandon attempts to replace the male spinners, their relatively high wages were resented. ${ }^{69}$ Matters came to a head in 1908 when employers reacted to the worsening crisis in the industry by attempting further to cut costs, and sacked large numbers of workers. The most dramatic events were to take place in the Rusiñol company town just outside Manlleu.

Conditions in the Rusiñol company town were, it has been noted, amongst the best on the Ter. Profit margins in the factory had, therefore, no doubt been particularly badly squeezed. This explains why on 15 May 1909 the owner, Albert Rusiñol, closed his factory and dismissed the 365 workers employed therein. The workers would, Rusiñol stated, have to reapply for admission, and accept a new wage list which had been drawn up. Not surprisingly wages were in the future to be considerably lower. In particular male spinners who worked on the ring-frames would have to accept a cut in wages of about 20 per cent.

The workforce replied that it would only accept wage cuts in those cases in which wages had actually been higher than in the other factories in the town. Rusiñol refused to compromise, so no solution to the dispute could be found. Thus, when the factory reopened on June 30 , the only people to go in were the managers and foremen. Another long strike ensued. The strikers were strongly supported by the Ter's textile unions. Rusinol tried to break the strike by sending agents out into the country to look for blacklegs, but he had little success: by November only 40 had been recruited. The result was deadlock, which was only broken in February 1910 when Rusiñol announced that he was to close the factory.

The conflict had important repercussions within the Manlleu labour movement. Many workers in the Rusiñol company town still maintained close, paternal, relations with the management. It was for this reason that the employer-inspired friendly society was strongest in Rusiñol's factory. However, the lock-out produced a change of attitude amongst these workers. During 1909 feelings amongst the workforce were running very high against the "inhuman" and "tyrannical" Rusiñol. Consequently, the members of the friendly society entered into negotiations with the town's independent union, known as the Art Fabril. They then agreed to dissolve their own association and entered the Art Fabril en masse, "convinced at last of the wickedness of the employer class". ${ }^{70}$

The events of 1909 showed once again how difficult it was to find a compromise solution to industrial disputes in cotton textiles. In the context

${ }^{69}$ The occasional attempt was still made to substitute men or women on the ring-frames. A case in point was the Baurier company town outside Roda. SO, 8 January 1909.

${ }^{x}$ SO, 4 June 1909; La Internacional, 28 May 1908; LP, 2 June, ME, 7 June, Night Edition [hereafter NE], 12 June, NE, 1909; El Progreso, 3, 4 and 5 July 1909; LJS, 6 November, 4 December 1909, 19 February, 17 September 1910; AMM, Gobernación, pp. 149, 395. 
of a seemingly permanent crisis in the cotton textile industry the mill owners were prepared to go to great lengths to push through their costcutting reforms. In the Alt Llobregat they had been able to impose social control, with the result that the workers in those areas were able to form no independent unions prior to World War One. On the Ter, however, their attempt to outlaw trade unions and cement a paternalist relation between masters and men had proved unsuccessful. Indeed, with the closure of the Rusiñol company town and the demise of the friendly society, any organised paternalist link with the workers was broken.

A pall of mutual mistrust and suspicion hung over industrial relations on the Ter. Open class warfare was not, however, resumed until 1914. In July 1909 anticlerical riots spread throughout much of urban Catalonia. The subsequent government repression greatly weakened the labour movement, and put paid to the attempt to form a Catalan wide textile federation. In July 1913 cotton textile trade unions remained weak, with only about 10 per cent of the industry's workers organised. That year, nevertheless, was to see the beginnings of another revival in the fortunes of the textile unions. The revival was on this occasion led by a Barcelona union known as $L a$ Constància, which was made up largely of female cotton textile workers. $L a$ Constància was founded in 1912, and grew rapidly in the following year. By July 1913 is had about 8,000 members, a figure which represented roughly 44 per cent of the Barcelona cotton textile labour force. ${ }^{71}$

The rapid growth of $L a$ Constància was facilitated by a boom in sales in the cotton textile industry during 1912. Nevertheless, it was still a great surprise to most contemporary observers. In Barcelona and the other textile towns, as has been noted, female weavers and preparatory workers had found it very difficult to unionise. Some employers had stepped in and developed a paternalist régime in their factories in order to increase the subservience of the labour force and head off possible conflict. The example of the two Fabra i Coat plants in the Barcelona Pla has already been mentioned. Another case in point was Catalonia's largest cotton textile factory, La España Industrial, which was situated in Sants. The factory owners provided loans for the workers when necessary, and continued to employ them on menial tasks in old age. The vision of the company director that was projected was that of a father who saw the workers as his own children. In this way it was hoped the workers would develop a sense of loyalty towards the company and gratitude to its director. In this the company certainly had some success. The sense of belonging was strengthened by the fact that generation after generation of the same family tended to work in La España Industrial. The rapport between master and men could be seen during the celebrations of the company's fiftieth anniversary

${ }^{71}$ ES, 18 April 1913; LP, 4 and 28 July 1913. 
in 1897. At these celebrations between 5 and 20 pesetas were given to each of the workers, and a raffle was held with sizeable cash prizes for the eldest employees. This prompted a commission of workers to present a message to the director of the factory, Matias Muntades, in which they expressed their gratitude. ${ }^{72}$

The extent to which the Barcelona cotton textile industrialists followed the lead of La España Industrial and instituted welfare programmes should not, however, be exaggerated. Thus, the reformist working-class magazine, Revista del Ateneo Obrero de Barcelona, commented that if more factories in Barcelona functioned like La España Industrial, then class conflict would be greatly reduced. ${ }^{73}$ The reason for the lack of effort in this direction was probably twofold. In part, many industrialists operated relatively smallscale plants, and lacked the capital outlays necessary. In addition, as we have seen, by the beginning of the twentieth century most of the cotton textile workers were female, and only worked in the factories for a few years before getting married. In such circumstances, it would have been difficult to operate welfare schemes effectively. Furthermore, the position of these workers on the shop floor was very weak. ${ }^{74}$ As a result, most industrialists probably felt they could maintain social control effectively without the extra cost benefit schemes entailed.

The fact that female cotton textile workers were unskilled, and that many spent only a few years in the labour market, together with employer hostility to unions, were the main obstacles in the path of their organisation. Moreover, the attitude of male trade unionists was not always helpful. ${ }^{75}$ It was because of these difficulties that between 1891 and 1914 the Barcelona cotton textile workers were effectively able to unionise only on two occa-

${ }^{72}$ La España Industrial en su 82 Aniversario, 1874-1929 (Barcelona, 1929), p. 94. See also, ETN, 30 May 1897; Revista del Ateneo Obrero de Barcelona, June 1897.

${ }^{7}$ Revista del Ateneo Obrero de Barcelona, June 1897; Moreover, Miguel Renté, one of the magazine's principal writers, lamented that friendly benefits had only been established in two factories from Sant Martí and one from Barcelona. Op.cit., pp. 75-76.

${ }^{74}$ Indeed, reports suggest that at the turn of the century in the larger Barcelona concerns the female power-loom weavers were subject to close managerial supervision, and that talking was not permitted while work was in progress. Pau Vila, "Records d'un Treballador", L'Avenç, 9 (January, 1978), p. 27.

${ }^{75}$ As we have seen, most men considered female employment as something transitory, to be undertaken by young unmarried women. Many had to accept the employment of their wives in order to supplement family income. Nevertheless, they continued to view the use of female labour, while male workers were unemployed, as an unacceptable imposition on the part of the industrialists. Accordingly, they found it difficult to accept female workers as an integral part of the labour movement. This explains why syndicalist labour leaders frequently complained that in spite of the fact that male skilled workers and female textile workers often formed part of the same family, the male trade unionists did little to try and unionise the women. See, SO, 23 July 1911; LJS, 5 August 1911; El Sindicalista, 26 October 1912. 
sions. The first was at the end of 1901 and the second, as has been seen, in 1913. In part the workers were able to unionise as a result of the efforts of pioneering female trade unionists, of which the most famous was the anarchist propagandist, Teresa Claramunt. However, on both occasions the Barcelona labour movement was buoyant, and male trade unionists overcame their indifference to play a key role in the organisation of the Barcelona weavers.

These male trade unionists tried to unionise the female weavers for two main reasons. First, the working conditions of many skilled workers were also under threat from their employers. These workers had formed unions to defend their interests. In order to bring the maximum pressure to bear, however, it was important that the Barcelona labour movement as a whole was as strong as possible. The Barcelona textile workers represented about 15 per cent of the city's working class, and their unionisation would therefore increase the influence of labour on the local political stage. In the second place, there still persisted the hope amongst male trade unionists that if they were able to unionise the female weavers and bring their working conditions up to the same level as male workers, they would then be able to replace the female by male weavers. ${ }^{76}$

The call for the reduction of working hours was, nevertheless, the Barcelona cotton textile workers' foremost demand, for while they worked an average of 11 hours a day, most skilled men worked only 8 or 9 hours. Once unionised these female weavers adopted a very combative stance. They had had to suffer for years in silence and were, therefore, hungry for justice. Their mood was very much in tune with anarchist trade-union practice. This could be seen in November 1901 when a new union, known as the Art Fabril de Sant Marti de Provençals, was formed. A campaign was launched by syndicalist trade unionists to unionise the weavers towards the end of the year. On 18 November the first seven workers to have joined the new union in the Nadal cotton mill were sacked. However, to the owners' surprise a great solidarity movement followed. The whole of the labour force in the Nadal factory came out on strike, and a large number of meetings were held in support of the strikers. Rocked by these events the employers gave way and, moreover, made a compensation payment of 125 pesetas to the strike's organisers. Spurred on by this success, the female weavers flocked to join the new union.

\footnotetext{
${ }^{76}$ See SO, 16 November 1907. As in the Alta Muntanya these demands seem to have received considerable support from the female workers concerned. This was revealed in an article written by Adela Camprubí, a female power-loom weaver who spoke at a number of rallies held to organise the cotton textile workers in 1901. She argued: "It is essential that union organisation spread from factory to factory, and loom to loom. That we should make a start, in order first to reduce working hours, and later to hand over our machines to the men, our beloved colleagues". El Productor, 16 November 1901.
} 
There was a great deal of enthusiasm, and an eagerness to enter into combat against the employers. Accordingly, in February 1902 the female weavers seconded a general strike called by anarchist militants in support of the striking Barcelona metalworkers. The general strike, however, ended in failure, and as a result the mood of the workers changed completely. The great energy displayed in previous months was replaced by a feeling of disillusion and despondency. This sense of despair was accentuated by the relative ease with which industrialists were able to victimise union militants. As a result, the mill owners were able to take advantage of the failure of the February 1902 strike totally to destroy the new union. ${ }^{7}$

A similar pattern emerged when the Barcelona cotton textile workers next organised in numbers during 1912-1913. La Constància was anarchist dominated. Its central committee, made up totally of men, did try to strengthen textile union organisation throughout the region. In the Spring of 1913 it established contact with the Sabadell and Terrassa woollen textile unions with the object of forming yet another Catalan textile federation. The efforts of these unions were soon to bear fruit. On 11 and 12 May delegates from a number of textile unions met in Barcelona and founded the so-called Federació Regional Fabril de Catalunya. As in 1900 the formation of a new federation gave a great impetus to the spread of trade unionism amongst the textile workers. Little progress was made in the Alta Muntanya, but in the textile towns around Barcelona trade-union organisation again grew apace. ${ }^{78}$

This organisational phase was, however, to be short-lived. The female cotton textile workers were anxious that their working conditions be improved. In a meeting held on 8 June the Federació Regional outlined its position. Its main demand was for a nine-hour working day in the industry. Moreover, it was agreed to call a strike if its demands were not met. ${ }^{79}$ The FTN was presented with these demands on 16 June. In the following days a large number of meetings were held at which there were frequent references to the need for strike action. However, a general strike was called in the industry before even the most militant union leaders had imagined. In the previous week the Government had become increasingly worried at the prospect of a general strike in Catalan textiles. It, therefore, proposed that the Instituto de Reformas Sociales, a body set up by the authorities in 1901 to oversee the implementation of social legislation, intervene and prepare a law which would regulate working conditions in the industry. At the same time it also made an effort to ensure that social legislation regulating child and female labour was complied with. It was this decision to try and

$\pi$ El Productor, 9, 16, 23 and 30 November, 7 December 1901.

78 SO, 1 and 17 May 1913.

${ }^{79}$ LP, 23 July 1913. 
implement existing legislation which was to precipitate the conflict. For the first time the civil governor insisted that legislation limiting the night shift for female workers to 11 hours be complied with. However, a number of factories in Sants responded simply by cutting night work. This decision produced great indignation amongst the textile workers, leading to widespread calls for strike action. It was in these circumstances that delegates from the Federacio Regional met on 25 July. At this meeting it was agreed that La Constància elect the federation's executive committee, and that this committee should call a strike when it saw fit. The committee's room for manoeuvre was very limited. On 29 July the workers from other Sants factories began to come out in solidarity with the sacked women. The committee was then pushed along by rank-and-file militancy and, fearing that once initial enthusiams had worn off it would be very difficult again to mobilise the female weavers, it decided to call a general strike that very night. ${ }^{80}$

Once declared the strike spread quickly. Thus by 22 July almost all the city's cotton textile workers had come out. Outside Barcelona the strike was seconded by the Mataró hosiery workers, and the Sabadell and Terrassa woollen textile workers. In the cotton textile industry, workers from a number of textile towns around Barcelona also came out in support. In the Alta Muntanya, on the other hand, union organisation was too weak, and the strike call was not heeded. Nevertheless, by the end of the first week it was claimed that up to 50,000 textile workers were on strike. ${ }^{81}$

The Barcelona civil governor was quick to claim that the strike was seditious and revolutionary in nature. However, the Liberal Government in power was anxious to reach a settlement, especially as the Catalan railway workers had threatened to come out in support if the textile workers' demands were not met. The first problem the Government faced in this respect was that the textile industrialists had no regional federation. The civil governor, therefore, tried to work through the FTN. The FTN's president, Eduard Calvet, was asked to consult with the cotton textile industrialists to ascertain the maximum concession they were willing to make. After consulting with about 40 textile industrialists, he informed the civil governor that they would not reduce working hours below sixty per week. The civil governor then called the strike committee and informed them of a Government plan to resolve the dispute, which consisted of the introduction of a bill in Parliament which would limit working hours in textiles to ten a day. ${ }^{82}$

${ }^{80}$ LP, 31 July, 18 and 27 August 1913.

81 LP, 28 July, 2 August 1913; LJS, 23 August; IRS, La Jornada, pp. 599-603.

22 LP, 1, 4 and 6 August 1913; IRS, La Jornada, pp. 599-603. 
The Government's formula by no means met with unanimous approval. Nevertheless, on 10 August a meeting of Federació Regional delegates agreed to accept the offer. Especially favourable were the delegates from outside Barcelona, for whom a sixty-hour week represented a significant reduction in working hours. The civil governor, thinking that the dispute was over, responded by asking the textile employers to open their factories the following day. However, the delegates' resolution still had to be put to the Barcelona strikers in a meeting to be held that evening. The majority of the audience at this meeting was made up of women. When the president announced that the Government's formula had been accepted there was uproar. Most radical in their opposition were the female workers, with one speaker going as far as to say, "that if the men are frightened they should retire, and let the women continue the strike". Many of the female workers were reluctant to abandon their demand for a nine-hour day, and all were unwilling to accept the Government's word that it would introduce a bill reducing the length of the working week when they returned to work. This fact contradicted the claims which were sometimes made by male trade unionists that female workers were invariably more docile and easier to exploit than their male counterparts. The intransigent stance adopted by the female weavers again demonstrated the radicalism of this group of workers. They had been unable to voice their demands since 1901, and vented their pent-up anger and frustration as soon as it was possible to organise. ${ }^{83}$

The Government's reaction to the vote against its proposal was to put a heavy guard on the factories, and hope that most of the strikers would return to work in the following week. Once this proved not to be the case it agreed immediately to publish a Royal Decree reducing working hours if the workers called off their action. In a meeting on 16 August, after hearing the Government's new offer, the leadership of La Constància and representatives of the Federació Regional again agreed to accept. Once more, however, the female weavers would have none of it. The situation, there-

${ }^{83}$ IRS, La Jornada, pp. 510-513. The link between the radicalism of the power-loom weavers, and the difficulties they faced when trying to unionise was noted by the more reformist sectors of the bourgeoisie. Thus, La Vanguardia stated in August: "It must be admitted that part of the blame for the slavery (of the textile workers) lies with the employers and the conservative classes who, with short sighted and selfish criteria have obstructed all serious organisation on the part of the workers. It is true that organised workers are a danger to many pockets and many insatiable strong boxes, but unorganised workers are an even greater danger to society. They are the raw material of all tumults, as soon as anyone ill-intentioned stirs up the flames of revolt. Those of us who defend biological nationalism must hope that the workers will organise, thereby sanctioning the work of nature [ . . ]. That is socialism? It is preferable that it should be socialism - which on the other hand it is not - rather than anarchism or perpetual chaos." LP, 9 August 1913. 
fore, appeared to be deadlocked. However, in the following week two factors worked against the strike's prolongation. First, the workers from textile towns outside Barcelona began to return to work, and the Federació Regional delegates publicly called on the Barcelona workers to follow suit. Second, the unity until then displayed by the female strikers showed signs of breaking up. A key factor behind their ability to resist so long had been the fact that in many households their wages supplemented those of the male members of the family. While the men continued to work, therefore, the household economy was not totally disrupted. None the less, their will to resist was now being sapped, leading to a slow return to work. There were fears that in the following week this trickle would become a flood. For this reason in a meeting held on the Friday it was reluctantly agreed that work would begin on the following Monday. ${ }^{84}$

The final act of the great Catalan textile strike of 1913 was now to be enacted. It began with an employer revolt against the more reformist elements in their midst, and ended with the formation of a new Spanish textile federation, which adopted a significantly more radical stance than any of its predecessors. Both these developments are of key importance for our understanding of the nature of social conflict in early twentieth-century Catalonia.

Eduard Calvet, the president of the FTE, had been entrusted by the Government to find a solution to the dispute acceptable to the employers. Calvet was himself a substantial cotton textile manufacturer. Nevertheless, he was not a typical example of the cotton textile bourgeoisie. Like other leading figures in the FTE he adopted a conciliatory stance, and throughout the dispute he made great efforts to reach a compromise acceptable to both sides. Until the end of the dispute it appeared that his efforts were supported by most of the employers. This, however, was soon to prove an illusion. Calvet had in the main consulted with relatively large-scale employers with factories in Barcelona. For these men the reduction in working hours conceded would not be a great sacrifice. In the Alta Muntanya, however, where working hours were considerably longer, the industrialists had far more to lose. Accordingly, they were the first to complain at the Royal Decree. They were, nevertheless, followed by a large number of Barcelona industrialists. Apparently, these men had been too afraid to voice their dissatisfaction at the compromise proposed by Calvet whilst the strike was in progress. Once it was over, however, they quickly rallied against the Royal Decree.

The industrialists' first move was to organise a meeting on Monday 25 August, the day work was supposed to restart, at the headquarters of the FTE. It was presided over by Josep Muntades, the director of La España 
Industrial, and attended by 230 employers from the Barcelona Pla and Alta Muntanya. The most important step taken at the meeting was to elect a commission to inform the Government of its views. The following day this commission presented the civil governor with a memorandum which called for the Decree to be suspended until 30 September, and for it to be implemented only after the question had been studied by the Instituto de Reformas Sociales; for traditional holidays to be included in the calculation of working hours; for government assurance that the workers would make no further demands over the next ten years; and for a series of limitations on the fines which could be imposed in case of non-compliance. The Minister of the Interior quickly rejected these demands, thus provoking a very violent reaction from the employers. ${ }^{85}$

This campaign had important repercussions within bourgeois circles. It did not receive the support of the FTN. As a result, a division opened up between the Foment and the cotton masters. This could be seen in a meeting called by Josep Muntades on 7 October. It was attended by a large number of industrialists from throughout Catalonia. At this meeting a new regional federation of cotton textile employers, known as the Federació de Fabricants del Pla i de la Muntanya, was founded in opposition to the FTN.$^{86}$ As a result of the 1913 textile strike, then, a majority of Catalonia's cotton textile industrialists formed a hard-line employer federation. This federation opposed the reformism of the FTN's leadership, was hostile to government social legislation, and refused to deal with independent trade unions.

Indeed, this federation was to a large extent able to ensure that the Government's decree was a dead letter. In Barcelona, when the workers began to resume work, some industrialists refused to implement the decree. At best a number agreed to work sixty-two rather than sixty-four hours a week. Similarly, in the Alta Muntanya, especially in those areas where there had been no strike, the industrialists made no move in the direction of reducing working hours. This attitude produced a feeling of great bitterness amongst the labour force, yet there was little union leaders could do to put pressure on the mill owners. Many of the unions which had participated in the dispute had been seriously weakened. La Constància in particular went into rapid decline. Disappointment over the result of the strike had led many female weavers to withdraw, whilst there also developed an internal

${ }^{85}$ In a letter addressed to the Home Secretary Josep Muntades stated that the workers had been forced out on strike, and that the movement was part of an international conspiracy which had also affected the industrial centres of France and Italy. He concluded that the Royal Decree would lead to a "civil war" in the factories. LP, 26 and 29 August; IRS, La Jornada, pp. 550-558. Anuari d'Estadística Social de Catalunya, Vol.II, 1913 (Barcelona, 1915), pp. 96-97.

${ }^{8}$ IRS, La Jornada, pp. 611-613. 
feud over the role played by the strike committee during the dispute. Moreover, the textile workers received little support from the state. Once the Royal Decree had been published the Government made very little effort to ensure it was enforced.

It was to try and stop the textile barons from ignoring the decree that the Mataró hosiery unions suggested that a congress be held to convert the Federació Regional into a national body. The congress was held in Barcelona between 25 and 27 December 1913. Only two unions from outside Catalonia affiliated, and delegates were in fact largely drawn from the same areas as previously. Nevertheless, the congress did give the textile unions an opportunity to express their reaction to the events of 1913. As in the case of the FTE both socialists and anarchists were represented. Nevertheless, the new organisation adopted a more radical tone than the FTE prior to its attempt to call a general strike in the industry. Thus, the TCV was excluded and declared "yellow and bourgeois", and as a direct result of this accord the historic textile federation was to be ignominiously wound up in the following year. During the sessions the Government was also heavily criticised for not having ensured the implementation of its own decree, and in a manifest published by the delegates the Instituto de Reformas Sociales was declared: "a useless body". It was furthermore agreed that if the sixty-hour week were not in the future enforced the federation's committee would, after having consulted with the membership, declare a general strike throughout the industry. ${ }^{87}$

Before the outbreak of the First World War, however, the only group of workers in a position to challenge the industrialists' refusal to implement the decree were those of the Ter and Freser valleys. In the Ter union organisation remained weak between 1910 and 1913 . However, the Government decree of 25 September 1913 heralded a revival of trade unionism in the area. By the beginning of 1914 these unions felt they were strong enough to issue their employers with an ultimatum. They, therefore, called for "a ten-hour day together with a 10 per cent increase in piece rates", and threatened immediate strike action if their demands were not met. The industrialists, however, refused to budge.

The workers responded by coming out on strike on 2 May 1914. The strike was seconded by over 15,000 workers throughout the Ter and Freser. Nevertheless, it was to prove a failure. The employers, whose profit margins were still under heavy pressure, would not hear of concessions. Moreover, after the strike of the previous year, the textile federation could offer little help. Yet, despite this failure, in the principal Ter Valley towns the unions ensured the return to work on the Ter was orderly, and that no

87 On this congress see, LP, 27 and 28 December 1913; SO, 1 January 1914; LJS, 3 and 10 January, 7 February 1914. 
workers were sacked. They, therefore, maintained a united front and, in the words of the correspondent of the Socialist weekly, La Justicia Social, successfully opposed any attempt on the part of the employers to impose "a regime of terror, similar to the one operating in the Alto Llobregat". 88

\section{Conclusions}

By 1914 , then, bitter industrial conflict was endemic in much of the Catalan cotton textile industry. During the early $1880 \mathrm{~s}$ it had briefly seemed that in urban areas it might be possible to set up collective bargaining procedures. Such hopes were, however, dashed by the employer offensive of 18891891. Thereafter the majority of industrialists were unwilling to negotiate with independent unions, and instead tried to use a mixture of coercion and paternalism to impose social control. In rural Catalonia the mill owners were able to outlaw trade unions without difficulty. In urban areas, however, it was not always that easy to stop workers from organising. Mill owners often did not have the resources to operate authoritarian regimes effectively, and it seems that, on occasion, competition between the industrialists inhibited a coordinated response to labour. ${ }^{89}$ Nevertheless, employers showed themselves determined to break the back of the textile unions even if this entailed an escalation of class conflict. It has been suggested that a key element in explaining the attitude of the cotton textile bourgeoisie was the economic crisis which hung over the industry from the mid-1880s.

Moreover, the tasks of the mill owners were generally made easier by the attitude of the authorities. The Spanish variant of the Liberal state forged during the nineteenth century was particularly authoritarian in nature, and left a key role in policing to the military. For the Spanish authorities union organisation and strikes were more often than not seen as a threat to the preservation of public order rather than a legitimate right. The Canovist Restoration, formed in 1875 , maintained this dominant authoritarian tradition. From the late nineteenth century even the official parties began to accept there was some need to integrate the working class into national political life. Yet moves in this direction were very tentative. Labour leaders were still subject to harassment, and periods during which more

\footnotetext{
8 LS, 1 November 1913: 17 and 31 January, 21 and 28 February, 28 March, 4 April 1914; SO, 26 March 1914; AMT, T. Trabajos Varios (2); AMM, Gobernació, S 152, A 398.

89 Industrialists in large-scale heavy industry found it easier to stop their workers from unionising. Hence before 1914 over much of Europe in the iron and steel industries unions were effectively banned. The best documented case is Germany. Nevertheless, in Spain the Viscayan industrialists adopted a similar policy. Juan Pablo Fusi, Política Obrera en el País Vasco (Madrid, 1975), pp. 129, 484-485.
} 
open union organisation was permitted were punctuated by bouts of repression. ${ }^{90}$

The hostility of the state towards organised labour was very much in tune with the demands of the country's ruling classes. The Castilian and Andalusian landowning lobby in particular was very powerful, and, given the low levels of productivity, it was only through breadline wages that the latifundia of Southern Spain were able to remain profitable. ${ }^{91}$ Not surprisingly, then, the landowning oligarchy was avidly opposed to trade unionism. The Catalan bourgeoisie was to a large degree marginalised from the centres of political power. However, until the turn of the century representatives of Catalan industrial interests had worked through the official Spanish parties. When they formed their own party - the Lliga Regionalista - in 1901 relations within the oligarchic parties became tense. However, as long as the Lliga was not perceived as posing any threat to national unity, as the "party of order" in Catalonia it could usually rely on state support."

The importance of these three interlocking factors - the economy, and the attitudes towards labour of industrialists and the state - is confirmed when a comparison is made with English experience. The raw class conflict which characterised social relations in the Catalan cotton textile industry through to 1914 bore a resemblance to the situation in England between the 1790 s and 1840 s. During these years the newly emerging working class faced blatant class legislation, and widespread employer hostility towards trade unionism. This is illustrated by the example of the spinners, whose attempts to form general associations were implacably imposed by the "steam lords" and the state. Not surprisingly, in these circumstances, the Lancashire and Cheshire cotton textile workers became strongly associated with the radical social and political demands of Chartism..$^{93}$

${ }^{90}$ In this article the role of the state in labour disputes has been stressed. However, in order to analyse the alienation of Catalan workers from the state more fully other factors such as its inability to enforce social legislation and the backwardness of the social security system, the manipulation of elections, and the unpopularity of the colonial wars, would need to be discussed. For the importance of these factors in the "(non) integration" of national working classes see, Marcel van der Linden, "The National Integration of European Working Classes (1871-1914)", International Review of Social History, XXXIII (1988), pp. 285-311.

${ }_{91}$ See, for example, Josep Fontana, "Transformaciones Agrarias y Crecimiento Económico en la España Contemporánea" in Josep Fontana, Cambio Económico y Actitudes Políticas en la España del Siglo XX (Barcelona, 1973), pp. 189-190.

${ }_{92}$ Borja de Riquer, "El Conservadurime Polític Català: del Fracàs del Moderantisme al Desencís de la Restauració", Recerques, 11 (1981), pp. 29-80; Joseph Harrison, “The Catalan Industrial Elite, 1898-1923", in F. Lannon and Paul Preston (eds), Elites and Power in Twentieth Century Spain (Oxford, 1990), pp. 45-70.

${ }_{93}$ R. Kirby and A. E. Musson, The Voice of the People: John Doherty (Manchester, 1975); H. I. Dutton and J. E. King, "The Limits of Paternalism: the Cotton Tyrants of 
However, social and political relations were transformed from midcentury. In perhaps the most convincing account of the onset of reformism in the northern textile towns, Neville Kirk has argued that from the 1850s the stabilisation of capitalism and rapid economic expansion, "greatly enhanced the scope for class manoeuvre, for concessions and initiatives towards labour 'from above', and the advancement of sections of the working class within the system [ . . ]". ${ }^{94}$ Thus, in the third quarter of the nineteenth century both liberal and conservative governments adopted a conciliatory stance, and enacted legislation favourable to labour. This included a number of factory acts. In cotton textiles the operatives achieved a $56^{1 /} / 2$-hour week in 1874 . Middle-class opinion towards trade unions remained more hostile than with respect to other branches of the labour movement. Nevertheless, in the early 1870 s the unions' right to operate legally was fully recognised. Because of these concessions from above working-class institutions were able to grow and prosper. Accordingly, they were increasingly drawn into the system, and began to abandon their radical social and political vision in favour of piecemeal reform. The cotton unions found it harder than other working-class institutions to gain middleclass acceptance. Nevertheless, as was noted in the introduction, by the 1880 s they had established bargaining rights with employers. At the same time, improvements in the cotton workers' standard of living and reductions of working hours also led to a growing acceptance of capitalism. ${ }^{95}$

The English mill owners were, in the second half of the century, increasingly predisposed to accept trade unions, and not provoke costly strikes if possible, because they operated highly productive concerns, and had at their disposal large internal and overseas markets. The more conciliatory stance of the English compared to Catalan employers could be seen in the fact that there was no comparable drive to replace male by female labour. On the spinning side of the industry the difference in attitude between the Catalan and English employers was, in particular, reflected in their respective reaction to the appearance of the ring-frame as a viable alternative to the self-acting mule. In England the ring-frame was first used in the 1870s. Yet, the English industrialists made no attempt to oust the male spinners and replace them with female workers. On the contrary, despite the higher productivity of the ring-frame, English industry continued to use male workers on the self-acting mules. In order to counter the

Lancashire, 1836-54", Social History, 4 (January, 1982), pp. 59-74; Neville Kirk, The Growth of Working-Class Reformism, pp. 54-72.

${ }^{94}$ Neville Kirk, The Growth of Working-Class Reformism, pp. xi-xii.

9s Ibid., passim. For stress on state "liberalisation", see also Gareth Stedman Jones, "Rethinking Chartism", in Gareth Stedman Jones, Languages of Class, Studies in English Working-Class History 1832-1983 (Cambridge, 1982), pp. 174-178. 
challenge of the ring-frames the spinners cooperated in the intensification of labour on the mules, and industrialists moved into higher counts of thread where the competitive advantage of the ring-frame was less notable. ${ }^{96}$

The harsher nature of social and political relations in Catalonia was, in fact, commented on by the TCV in the $1880 \mathrm{~s}$. At that time the establishment of a system of collective bargaining on the English model was the goal of the TCV leadership. In 1889, therefore, it sent a commission to England to study the reasons behind the greater stability of labour relations in that country. It concluded that the low level of industrial militancy in England was the result of two factors. First, the implementation of a large body of social legislation. Second, the existence of collective bargaining arrangements between workers and employers. ${ }^{97}$ The commission then went on to point out that in Catalonia over the past seven years the only branch of the industry in which a collective agreement had been in force was cotton printing.

Without wishing to adopt too reductionist an approach, there was also clearly a connection between the economic and social context within which workers lived and worked, and the ideological and political stance of the institutions which represented them. Thus, Neville Kirk has argued that with the growing integration of organised labour within capitalism after mid-century there was a slow shift amongst labour leaders away from Chartism and towards the class-collaborationist politics of Lib-Labism. In the late nineteenth century the cotton unions were hostile to socialism, feeling that their grievances could be rectified through the use of industrial muscle. This was particularly in the case of the well-organised spinners. ${ }^{98}$ From the beginning of the twentieth century inflation and a growing intensification of labour led to working-class discontent. Between 1910 and 1914 in particular cotton workers took advantage of the boom conditions

${ }^{90}$ William Lazonick, op. cit., pp. 253-255.

97 On this second point the commission stated that: "[ . . .] the docility (quietismo) of the English workers is the result of the assurances they receive from the employers' union, which maintains the collective agreements reached without any variation. It thereby offers confidence to the worker who, in return, offers peace to the employer. By this means the industry acquires continuity, that is to say life. The situation is very different to that of other countries and especially our own, which is the most in need of not suffering upheavals. Despite this, most industrialists do no accept the rights of labour, and prefer strikes, with the accidents that go with them, to a collective agreement with the workers." Memoria Descriptiva Redactada por la Comisión Obrera Catalana para Estudiar el Estado de las Fabricas de Hilados y Tejidos en Algodón en Inglaterra (Barcelona, 1889), pp. 6-7.

${ }_{98}$ Alan Fowler and Terry Wyke (eds), The Barefoot Aristocrats. A History of the Amalgamated Association of Operative Cotton Spinners (Littleborough, 1987), p. 119. 
and carried out a large number of strikes aimed at improving working conditions. However, the established trade-union leaderships were never seriously threatened, and bargaining machinery was maintained. ${ }^{99}$

In Catalonia, as has been stressed, workers were able to build up no such bargaining structures. Union leaders were, in fact, caught between two stools. On the one hand they were conscious of the need to be conciliatory in order to entice employers to negotiate with them. On the other they were radicalised by the experience of employer and state hostility. Thus, after the employer offensive of 1889-1891 the class-collaborationist TCV was largely discredited. Within the FTE during 1900 the reformist TCV leaders represented only one current of opinion. Both the anarchists and, in particular, the socialists, now had considerable influence. Nevertheless, under the guidance of socialist and independent trade unionists the goal of the FTE was, like that of old Catalan-wide TCV, to establish collective bargaining procedures with the mill owners. Hence, full-time officials were appointed and the rank and file urged not to take rash strike action which would endanger the organisation's future. Employers, it was reasoned, would not be convinced of the benefits of negotiation if the Federation could not control is own membership. Indeed, in Catalonia before 1914 it was only the textile unions that appointed full-time officials. This was, perhaps, due to the fact that at plant level most textile workers were in a weaker position than their counterparts in the artisanal trades. The appointment of full-time officials, it was probably hoped, would help protect individual union members from victimisation. The appearance of full-time officials may also help to explain why the Spanish socialists were stronger in cotton textiles than in any other branch of Catalan industry. The socialists did not condone the class-collaborationism of the TCV. Nevertheless, they favoured the organisation of bureaucratic labour federations, whose officials calmly negotiated wages and working conditions with the employers. Moreover, in a non-revolutionary context if the union was to survive there was little choice but to try and reach some form of agreement with the employers.

Yet at the turn of the century, it was once again to prove impossible to attain any form of agreement. And it was in desperation that workers came to adopt some of the tactics advocated by the anarchists. Hence, it was the employer onslaught in the late 1900 that drove the cotton workers to try and declare a general strike throughout the region. In Barcelona between 1901-1902 and 1912-1914 the anarchists were also to lead female weavers' trade unionism. The weavers were a group of workers who had found it very difficult to unionise, and once they had done so were anxious their griev-

99 J. L. White, The Limits of Trade Union Militancy. The Lancashire Cotton Textile Workers 1910-1914 (New York, 1978). 
ances be immediately redressed. Not surprisingly, therefore, they were drawn to the anarchists' direct action tactics. When the textile workers were finally able to reorganise a regional federation in 1913 the dilemma of attempted negotiation or militant action was again to emerge. However, given their bitter experience most workers in the industry now seemed ready to condone general strike tactics if the need arose.

In conclusion, then, while one cannot explain workers' consciousness solely with reference to their work experience - such a task would necessitate a much wider-ranging study of the ideological context and the impact of the state on workers' lives - it can, nevertheless be argued that the radicalisation of the cotton workers is only comprehensible in the context of the employer offensives against labour, and the support that, at crucial times, the mill owners received from the state. As such the study of social relations in the cotton textile industry adds an important element to our understanding of the reasons behind the alienation of the Spanish working class from the state and ruling classes. 